This PDF is a selection from a published volume from the National Bureau of Economic Research

Volume Title: Producer Dynamics: New Evidence from Micro Data

Volume Author/Editor: Timothy Dunne, J. Bradford Jensen, and Mark J. Roberts, editors

Volume Publisher: University of Chicago Press

Volume ISBN: 978-0-226-17256-9

Volume URL: http://www.nber.org/books/dunn05-1

Conference Date: April 8-9, 2005

Publication Date: January 2009

Chapter Title: The Role of Fringe Benefits in Employer and Workforce Dynamics

Chapter Author: Anja Decressin, Tomeka Hill, Kristin McCue, Martha Stinson

Chapter URL: http://www.nber.org/chapters/c0498

Chapter pages in book: (473 - 505) 


\title{
The Role of Fringe Benefits in Employer and Workforce Dynamics
}

\author{
Anja Decressin, Tomeka Hill, Kristin McCue, and \\ Martha Stinson
}

\subsection{Introduction}

A growing literature in economics examines the role of human resource practices in determining firm performance. One strand of this literature has focused on how compensation design can affect employee incentives and through them, a firm's success. Fringe benefits are an important share of compensation, and economists have long studied the role of pensions and health insurance in labor markets, but have devoted relatively little attention to how decisions about benefits might interact with firm performance. Our aim here is to pull together these issues by examining how providing part of compensation to employees in the form of benefits interacts

Anja Decressin is an economist in the U.S. Department of Labor. Tomeka Hill is a senior research associate at Watson Wyatt Worldwide. Kristin McCue is an economist at the U.S. Census Bureau. Martha Stinson is an economist at the U.S. Census Bureau.

The authors wish to acknowledge the substantial contributions of LEHD staff, in particular Paul Lengermann, Kevin McKinney, and Kristin Sandusky. We wish to thank John Abowd, Dan Beller, Keenan Dworak-Fisher, Julia Lane, Joe Piacentini, participants at the pre-conference, and especially our discussant, Dan Black, for their comments.

This document reports the results of research and analysis undertaken by the U.S. Census Bureau staff. It is released to inform interested parties of ongoing research and to encourage discussion. This research is a part of the Census Bureau's Longitudinal Employer-Household Dynamics Program (LEHD), which is partially supported by the National Science Foundation Grants SES-9978093 and SES-0427889 to Cornell University (Cornell Institute for Social and Economic Research), the National Institute on Aging Grant R01 AG018854, and the Alfred P. Sloan Foundation. The views expressed herein are those of the authors and not necessarily those of the Department of Labor, or of the Census Bureau, its program sponsors, or data providers. Some of the data used in this chapter are confidential data from the LEHD Program. The Census Bureau supports external researchers' use of these data through the Research Data Centers (see http://www.ces.census.gov/). For other questions regarding the data, please contact Jeremy S. Wu, Program Manager, Assistant Division Chief, U.S. Census Bureau. (Jeremy.S.Wu@census.gov, http://lehd.did.census.gov/). 
with a firm's human capital stock, and further, how this choice is related to firm productivity, growth, and survival. Clearly, whether and what sort of benefits to offer is not given exogenously, but is a decision that will depend in part on firm performance. Our goal is not to establish causality, but rather to map out correlations among these variables as a building block for future work in this area.

We approach these issues using a very rich data set that combines administrative data on benefit plans from IRS Form 5500 with the Longitudinal Employer-Household Dynamics (LEHD) integrated employeremployee data. These data have many unique characteristics that allow us to explore how firm productivity, growth, and survival are related to benefit offering in a way that has not been possible before. Each data source provides a piece of the overall picture. The data from IRS Form 5500 provide us with the means to identify which employers offer benefit packages, as well as some information about the type of benefits offered. These public filings cover most types of tax-preferred benefits, enabling us to characterize the benefit offerings of a much broader group of employers than would be possible with survey data.

The firm-level data, drawn from the Census Business Register and State ES-202 data, report other firm characteristics such as firm size, industry, number of establishments, and a longitudinal measure of firm life span. The worker-level data, drawn from State Unemployment Insurance (UI) wage records, inform us about which workers are employed by which firms in a quarter and give us some basic demographic characteristics of those workers.

These links between workers and firms allow us to follow the movement of workers between firms and in and out of the labor market over time. These longitudinal links provide us with measures of human capital and firm compensation practices that are of key interest to questions about benefit offering. They also give us measures of the number of workers joining and leaving each employer's workforce, providing us with more detailed data on the amount of employee turnover than is available from either firm- or worker-level data alone. Employers' compensation choices are driven both by the characteristics of their businesses and the workforce that they choose to employ. By integrating these three different types of data-benefit offerings, firm characteristics, and worker flows-we are able to examine the whole picture. Because the data sources we draw on cover populations rather than samples, we can use a very rich combination of measures while retaining a reasonably large and representative sample - something that is very difficult to obtain when combining data from several surveys. We use these data to measure how firm choices about compensation packages are correlated with a firm's workforce turnover and growth and how both of these are in turn correlated with firm outcomes. 
The chapter proceeds as follows. In section 13.2 we briefly discuss the literature that we build on and present a framework for thinking about our estimation. We discuss data issues in some detail in section 13.3, and then present results in section 13.4. Section 13.5 summarizes our results.

\subsection{Background}

As background for our empirical work, we briefly review related work on human resource practices and firm performance to give a context for our approach. Following that we provide a framework for our estimation.

\subsubsection{How do Firms Use Benefits to Shape Their Human Capital Stock?}

In hedonic wage models, workers face a continuum of different compensation packages given by the envelope of firms' varying wage/benefit isoprofit lines. ${ }^{1}$ In response to this set of choices they sort themselves into different types of firms. Variation in workers' willingness to trade off wages for benefits leads to sorting of workers into firms on the basis of fringe benefit offerings. In this model, sorting matches workers with their preferred compensation package and minimizes employers' costs of employing labor.

Workers vary in their willingness to trade off wages for benefits because of differences in factors such as marginal tax rates, age, and rates of time preference. Firms that need skills held mainly by young workers, for example, might make themselves more attractive to the employees they wish to hire and keep by offering higher wages and no benefits, if young workers have a lower willingness to trade off cash wages for fringes. The relative cost of fringe benefits may vary across firms because of economies of scale in providing benefits or varying access to particular types of fringe plans. For example, large firms may have lower costs of providing benefits because of the cost advantages of pooling across a large group of employees. As Montgomery and Shaw (1992) point out, any direct productivityenhancing effects of benefits will also alter the firm side of this trade off, increasing the cost effectiveness of fringes relative to wages.

Alternatively, dual labor market theory posits that there are two sectors: one with rationed good jobs that pay well and have good fringe benefits, and a second with bad jobs having low pay and few benefits (Bulow and Summers 1986; Dickens and Lang 1985). Sorting in this model need not reflect differences in the costs of providing benefits, nor in willingness to trade off wages for fringes. Similarly, efficiency wage models also generate an equilibrium in which workers with the same productive characteristics would have jobs with different levels of compensation that might include different benefits. 
A long literature has documented that both pensions and health insurance are associated with a workforce with lower turnover. Economists have found a negative relationship between pensions and quit rates for both defined benefit (DB) and defined contribution (DC) plans. ${ }^{2}$ In the case of DB plans, implicit contract theory has been the primary framework used to interpret this pattern: a loss of pension wealth penalizes workers who break their implicit contract by leaving prior to retirement. This compensation structure leads to self-selection so that firms offering pensions end up with a workforce made up of stayers, which is what motivates offering the DB plan.

Ippolito (2002) offers an alternative explanation. One problem for implicit contract theory has been the finding that quit rates are low for firms offering DC plans as well as those offering DB plans, despite the fact that DC plans impose much smaller quitting costs (Gustman and Steinmeier 1993 and 1995; Even and Macpherson 1996; Ippolito 2002). Ippolito argues that quit rates are low because pensions in general attract savers, and that those who save at a higher rate also have lower quit propensities. His 2002 paper expands on earlier work (Ippolito 1997) that argues that having a low discount rate makes both saving and staying more attractive, so pensions are one method of attracting those with low discount rates who may also have higher productivity. He presents evidence that those with characteristics that might be correlated with a low discount rate are more likely to have a pension, and are also more likely to have high performance ratings.

An alternative explanation for low quit rates under pension plans is that firms with pensions have higher total compensation than firms without, and that the difference in compensation accounts for lower turnover (Gustman and Steinmeier 1995; Even and Macpherson 2001). Gustman and Steinmeier (1995) point out that compensation differences would help explain some other puzzles as well - why the reduction in turnover associated with pensions is largest for young workers, for whom the associated pension losses are small, and why the reduction appears to occur primarily through fewer layoffs rather than through fewer quits.

If benefits play an important role in firms' compensation strategies, there ought to be measurable effects on firm outcomes such as productivity, firm growth, and survival. Such effects may come about indirectly through changes in the recruitment and retention of labor. But benefits may also affect productivity more directly by altering employees' incentives to invest in firm-specific knowledge or by reducing turnover and training costs (Even and Macpherson 2001). There is little existing empirical evidence on the relationship between benefits offering and productivity. One exception is work by Dorsey, Cornwell, and Macpherson (1998) using Compustat data to estimate effects of DB plans on productivity us-

2. See, for example, the review in Gustman, Mitchell, and Steinmeier (1994). 
ing a production function framework. They find evidence of higher labor productivity in firms with DB plans, but the evidence on overall productivity effects is mixed.

\subsubsection{Schematic Framework for Our Empirical Work}

Our starting point is to posit that productivity is a function of a firm's human capital stock $(H C)$ and other inputs $(Z)$.

$$
\ln Y_{i t}=f\left(H C_{i t}, Z_{i t}\right)+\varepsilon_{i t} \text {. }
$$

We assume that the composition of compensation affects productivity through its effects on the human capital stock. A traditional representation of the evolution of a capital stock is useful in considering the mechanisms through which this might happen:

$$
H C_{i t}=\left(1-\delta_{i t}\right) H C_{i, t-1}+I_{i t}
$$

where $H C_{i t}$ represents the human capital stock of employer $i$ at time $t$, and $I_{i t}$ represents investment. Investment in human capital happens through accessions (new hires) and on-the-job acquisition of skill by current employees. Depreciation occurs both through employee separations and through deterioration or obsolescence of employees' skills. Because we cannot measure on-the-job investment or the deterioration of skills, we focus on how compensation practices affect accessions and separations. We do so by running a series of regressions to examine differences in churning (turnover in excess of that needed to grow or shrink a firm) and net employment growth for benefit- and non-benefit-providing employers. If benefit provision is correlated with lower churning and net employment growth or stability, this will support the findings of previous studies that benefits are associated with lower turnover.

We then come back to equation (1), and estimate the correlation between output and changes in $H C$ by running a series of productivity regressions. Our ability to measure the other inputs, $Z$, is quite limited. Outside of manufacturing, we have no direct measures of other inputs, so we rely on controls for industry, location, and size to capture some of these effects. We are in somewhat better shape in manufacturing where we can at least measure capital-labor ratios and the use of materials, so we present some of our productivity results for manufacturing alone. A positive correlation between benefits and productivity will support the hypothesis that firms are choosing benefit packages to attract and retain high quality workers, or at least workers whose skills closely match the firm's needs. Finally, using the data we have developed on a firm's human capital stock, productivity, and benefits, we look at what relationship fringe benefit compensation has with a longer run firm outcome - the likelihood of firm failure. We estimate hazards of firm death to examine how the human capital stock, productivity, and fringe benefit compensation are correlated with 
firm survival. A positive correlation between longer firm life and benefit provision will be consistent with the hypothesis that firms gain real advantage from choosing a compensation package that involves pensions and health insurance, though it could also be that expected firm success makes employers more willing to offer benefits.

\subsection{Data}

Our estimates are based on a very rich database that we created by combining data from several sources. It consists of microdata on whether a business provided benefits, detail on the types of benefits provided, workforce composition, turnover, the distribution of worker earnings, and labor productivity. Much of this data is also longitudinal, allowing us to measure changes in benefit offerings, and firm survival and growth.

\subsubsection{Dataset Construction}

The database combines information from five sources:

- Firm reports on benefit plans offered to employees (the Internal Revenue Service/Department of Labor Form 5500 file)

- The Census Bureau's Business Register (BR)

- Unemployment Insurance (UI) wage record data from seven states

- The Census NUMIDENT file

- The Economic Census

Benefit information comes from Form 5500 annual reports on employee benefit plans filed by the plan sponsor (usually the employer). These public filings are required under ERISA for most types of tax-preferred benefits, with some exemptions for small health plans. Here we use data on plans that end in 1997 and 2001, drawing from the 1996/1997 and 2000/2001 data files. The Form 5500 collects information about employer-provided pensions (defined benefit and various types of defined contribution plans), welfare plans (health, life, supplemental unemployment, and disability insurance plans) and fringe benefit plans (cafeteria or flexible benefit plans and educational assistance plans). ${ }^{3}$ In addition to variables describing plan features, the data also include name, address, and a federal Employer Identification Number (EIN) for the plan sponsor. Employer Identification Numbers (EINs) are also used in a wide variety of other employer tax filings, including those underlying the Census Bureau's business list and the UI wage record data.

Figure 13.1 describes how the data set is constructed. The 5500 file is first integrated with Census's Business Register (BR) using sponsor EINs. The $\mathrm{BR}$ is a list of all private establishments with paid employment that is con-

3. See appendix table 13A.1 for a listing of the benefit plan types and the associated frequencies among 1997 plans in the 5500 files. 


\begin{tabular}{|l|l|}
\hline Form 5500 \\
EIN, Plan Number
\end{tabular}$\longrightarrow \begin{aligned} & \text { Census Bureau Business Register } \\
& \text { EIN, Alpha }\end{aligned} \longrightarrow \begin{aligned} & \text { State ES-202 data } \\
& \text { EIN, Year }\end{aligned}$

\begin{tabular}{|l|l|l|}
\hline $\begin{array}{l}\text { 1. Create EIN level record with } \\
\text { summary information for benefit plans }\end{array}$ & $\begin{array}{l}\text { 2. Match Form 5500 data to BR } \\
\text { by EIN and year, add alpha }\end{array}$ \\
$\qquad$\begin{tabular}{|l|l|}
\hline $\begin{array}{l}\text { 3. Collect all EINs } \\
\text { associated with alpha } \\
\text { Create augmented EIN list }\end{array}$ & $\begin{array}{l}\text { 4. Match to State ES-202 } \\
\text { UI data using EINs from } \\
\text { augmented list }\end{array}$ \\
\hline
\end{tabular} \\
$\begin{array}{l}\text { 5. Examine characteristics } \\
\text { of workers and firms }\end{array}$ \\
\hline
\end{tabular}

Fig. 13.1 Schemata for construction of database

structed from a variety of administrative and survey sources, but its backbone is quarterly employment tax filings that include EINs. ${ }^{4}$ Census uses the quinquennial economic censuses and the annual Company Organization Survey in constructing the BR to break out different business locations that may be filed under a single EIN. Many large firms use more than one EIN, so these survey sources, in combination with administrative data, also identify EINs that are affiliated through parent-subsidiary relationships.

We do an initial match of the list of 5500 EINs to the BR. If a 5500 EIN matches to part of a multi-location firm, we use information on company structure from the BR to identify any other EINs (and affiliated establishments) that belong to the same company. One difficult question is whether a particular benefit is in fact offered at all establishments belonging to a company. Here, we treat all parts of a company as offering benefits if at least one EIN belonging to that company matches to the 5500 file.

Our next step is to bring in the UI data. These data are described extensively elsewhere (Burgess, Lane and Stevens 2000), but we note several salient characteristics here. First, they include longitudinal data on both firms and workers from the mid-1990s to 2003, which permits an analysis of the dynamics of employment flows, workforce change, and firm entry and exit over this period. Second, because earnings data are available for individual workers at each of their employing firms, it is possible to analyze both earnings and employment outcomes for workers in each business. Finally, the data are almost universal in nature, capturing some 98 percent of employment in each state for which the data are collected. The results presented here include data for seven states.

Although the UI wage record data are very rich in terms of sample size

4. The BR was historically known as the Standard Statistical Establishment List (SSEL). An establishment is defined as a single physical location where business is conducted or where services or industrial operations are performed. 
and coverage, they lack demographic information on workers. Limited demographic information is obtained by matching the UI records with internal administrative records (the Census NUMIDENT file) that have information on date of birth, place of birth, race and sex for all workers. About 96 percent of the records in each state's UI wage data can be matched to this source. ${ }^{5}$

In addition, we make use of human capital measures constructed by other LEHD researchers. The LEHD staff (as described in Abowd, Lengermann, and McKinney [2002], henceforth ALM) have estimated fixed effects for individual firms and workers based on the following wage equation:

$$
\ln \left(w_{i j t}\right)=x_{i t} \beta+\theta_{i}+\psi_{j}(i, t)+\varepsilon_{i j t}
$$

where $\theta_{\mathrm{i}}$ is a fixed worker effect, $\psi_{j}(i, t)$ is a fixed firm effect, and $j(i, t)$ indexes the firm $j$ for which worker $i$ works at time $t$. $\operatorname{Ln}\left(w_{i j t}\right)$ represents the $\log$ of full-time earnings, so the fixed effects $\theta_{i}$ and $\psi_{j}(i, t)$ are in terms of log earnings differences. This decomposition provides a measure of the fixed, portable component of worker $i$ 's skills $\left(\theta_{i}\right)$, and a measure of the fixed premium (or discount) that firm $j$ pays after accounting for worker skills $\left(\psi_{j(i, t)}\right)$.

In our empirical results we use the following as a measure of general human capital:

$$
h_{i t}=x_{i t} \beta+\theta_{i}
$$

where $x_{i t}$ consists of quarters of work experience interacted with race and gender. As described in ALM, a seven-state distribution of $h_{i t}$ was created and individual workers were classified according to their location in this distribution. Summary-level statistics for firms were created by calculating the percentage of workers at each firm that belonged to each quartile of the overall human-capital distribution. In this work, we have these measures for 1997 only.

Finally, we bring in measures of labor productivity based on data from the 1997 Economic Census (EC). We measure labor productivity as the logarithm of sales per employee deviated from the two-digit industry mean. For multi-unit firms, we aggregate establishment-level data from the EC to the state-EIN-two-digit SIC level before matching to the 5500/UI data. For each multi-unit firm we define a primary SIC by aggregating payroll across establishments within a state that have the same two-digit SIC code, and then taking the SIC code associated with the largest aggregated payroll. ${ }^{6}$

5. See Staff of the LEHD Program (2002) for further discussion.

6 . Because at the time of writing data were not yet available from the 2002 Economic Census, we do not have longitudinal data on productivity. 


\subsubsection{Data Coverage Issues - 5500/Business Register Match}

In the results that follow, we use the presence of a matching record in the 5500 file as an indicator that a firm offers benefits and then use additional information from the file to determine what sorts of benefits are offered. Whether these are reasonably accurate measures depends first on the filing requirements for the Form 5500 (e.g., do all plans in fact appear in this data set?) and secondly on our success in matching an employer to the 5500 data set when it in fact contains information on the employer's benefit plan(s). We briefly describe these issues here; they are more fully documented in Decressin et al. (2005).

Filing requirements differ somewhat for pensions and other types of plans (welfare or fringe benefit plans). For pensions, only a few specialized types of plans are exempt from the requirement to file. ${ }^{7}$ However, welfare and fringe plans with fewer than 100 participants are exempt if they are either unfunded (i.e., the employer pays the costs out of general funds) and/ or fully insured through an insurance provider (e.g., a Blue Cross/Blue Shield company). Thus, most small health plans are probably not included in the 5500 file. Where we focus on benefits in general, the firms for whom we mismeasure benefit offering are those who offer a small health plan but no pension plan.

For most plans, employer and sponsor are one and the same, and integration of 5500 data with the BR is straightforward. However, for plans that involve multiple employers the sponsor EIN generally belongs to an entity other than one of the participating employers. For example, a trade union might sponsor a Taft-Hartley pension plan for unionized electricians working for many different employers. Given that we cannot identify which employers are involved with our current resources, we drop those plans in what follows.

Some employers offer more than one benefit plan, so we summarize plan-level information associated with the same EIN before matching to the BR. ${ }^{8}$ Ninety-seven percent of the 731,609 EINs in our 1997 Form 5500 extract can be found on the 1997 BR. Limiting our analysis to records in the BR that meet our criteria for being active and in-scope gives us a match rate of 90 percent for the 5500 EINs in 1997 and 89 percent for the EINs in $2001 .{ }^{9}$ The fraction of firms on the BR that match to a plan in the 5500 file

7. Simplified Employee Pension (SEP) plans are exempt, as are Savings Incentive Match Plans for Employees (SIMPLE) if they take the form of an IRA (but not SIMPLE 401(k) plans). Both plans can be used only by employers with at most 100 eligible employees. SEP plans do not allow for employee contributions, and employer contributions must be a fixed percentage of pay up to a maximum. Church plans are also exempt.

8. Thirty percent of EINs in 1997 are associated with two or more plan filings.

9. The BR records that we exclude from matching either do not report any payroll for the current year or have codes that indicate that they should be outside the scope of our investigation (e.g., they are government-owned entities, which are not required to file Form 5500, or 
Table 13.1

Business register match rates to 1997,5500 data

\begin{tabular}{|c|c|c|c|c|c|c|}
\hline \multirow[b]{2}{*}{$\begin{array}{l}\text { Number of } \\
\text { employees }\end{array}$} & \multicolumn{2}{|c|}{ Single-unit firms } & \multicolumn{2}{|c|}{ Multi-unit firms } & \multicolumn{2}{|c|}{ All firms } \\
\hline & Number & $\begin{array}{c}\text { Match } \\
\text { rate }(\%)\end{array}$ & Number & $\begin{array}{l}\text { Match } \\
\text { rate }(\%)\end{array}$ & Number & $\begin{array}{l}\text { Match } \\
\text { rate (\%) }\end{array}$ \\
\hline Missing or 0 & 955,116 & 1.5 & 2,880 & 16.6 & 957,996 & 1.5 \\
\hline $1-4$ & $2,624,082$ & 4.1 & 7,728 & 15.4 & $2,631,810$ & 4.1 \\
\hline $5-99$ & $1,918,184$ & 19.5 & 139,724 & 47.2 & $2,057,908$ & 21.3 \\
\hline $100-999$ & 44,708 & 62.3 & 44,166 & 78.5 & 88,874 & 70.4 \\
\hline $1,000+$ & 1,130 & 74.3 & 7,074 & 92.6 & 8,204 & 90.1 \\
\hline Total & $5,543,220$ & 9.5 & 201,572 & 54.0 & $5,744,792$ & 11.0 \\
\hline
\end{tabular}

Notes: Employment data on the BR come primarily from filings of IRS Form 941, which is used to report quarterly withholding of payroll and income taxes. Businesses are also asked to report employment on these forms, but the employment data are not as complete as the payroll data. We include only firms with positive payroll in the table (and the match), but some of these firms do not report any employment. This could be because the employment question asks about a particular week in the quarter and the firm had no employees on the payroll that week, or it may be that firms neglected to report employment, which is not directly tied to the tax liability. Employment data used in the estimation section is taken from the UI data.

is much lower. As tables 13.1 and 13.2 illustrates in 1997, only 11 percent (9.4 percent in 2001) of the 5.7 million businesses in the 1997 Census Business Register have a match to a 5500 form, but the vast majority of companies that do not match to the Form 5500 data are in fact very small. The match rates in 2001 are similar to the ones in 1997, but usually a little lower. ${ }^{10}$ Because we have a wider variety of data available in 1997 than in 2001 and we would like to be as consistent as possible across tables, in the following most statistics are only presented for 1997.

The low overall match rate simply reflects the predominance of firms with few employees in the overall count of firms. Of the nonmatches in 1997, 54 percent have five or fewer employees, and an additional 23 percent have between six and twenty-five employees. Large firms ( $\geq 100$ employees) account for only 0.5 percent of all nonmatches compared to 13 percent of all matches. Larger firms are more likely to offer benefits and are also more likely to be required to file Form 5500, given that they offer plans. Thus, it is encouraging that the majority of large firms in the Business Register can be matched to a Form 5500 filing. Because of filing exemptions and difficulties

represent a trust rather than an employer). The 11 percent of EINs in 1997 that match to these sorts of BR records might match to adjacent years of the BR, or may provide information on what sorts of plans we do not accurately match - both possibilities we plan to investigate in future work. Extensive documentation of the matching exercise is provided in Decressin, McCue, and Stinson (2003).

10. The data for the 1997 match did receive a much bigger data cleaning effort than the 2001 data and this might have caused better match numbers for 1997. 
in matching, we expect coverage to be incomplete for small firms and in industries with large numbers of Taft-Hartley plans. In some of what follows we present results for manufacturing alone (which has little Taft-Hartley coverage) or for the sample of firms with at least 100 employees.

If we weight these match rates by employment (see table 13A.2), firms in 1997 that match to the 5500 file employ 66 percent of all workers (70 million out of the 106 million in the 1997 workforce). The corresponding number for 2001 is 64 percent. Among multi-units the match rate is even higher: 90 percent of workers in 1997 are employed by matching firms ( 89 percent in 2001), compared with 36 percent for single-unit firms (32 percent in 2001).

Table 13.3 gives the distribution of type of plans among firms that match to at least one plan in 1997. A very large share of firms with some sort of matched benefit offer a pension plan, regardless of size. This probably reflects the fact that coverage of benefits by Form 5500 filings is most complete for pensions. The most notable size effect is for health plans, for which the percent offering a health plan is substantially larger for firms with greater than 100 employees. This appears to reflect the exemption from filing for most health plans with fewer than 100 enrollees.

Comparing benefit coverage rates implied by our matched data to national survey estimates suggests that we do quite well in matching pension

Table 13.2

Business Register Match Rates to 2001, 5500 Data

\begin{tabular}{|c|c|c|c|c|c|c|}
\hline \multirow[b]{2}{*}{$\begin{array}{l}\text { Number of } \\
\text { employees }\end{array}$} & \multicolumn{2}{|c|}{ Single-unit firms } & \multicolumn{2}{|c|}{ Multi-unit firms } & \multicolumn{2}{|c|}{ All firms } \\
\hline & Number & $\begin{array}{l}\text { Match } \\
\text { rate }(\%)\end{array}$ & Number & $\begin{array}{l}\text { Match } \\
\text { rate }(\%)\end{array}$ & Number & $\begin{array}{l}\text { Match } \\
\text { rate (\%) }\end{array}$ \\
\hline Missing or 0 & 929,468 & $1.3 \%$ & 3,117 & $18.7 \%$ & 932,585 & $1.37 \%$ \\
\hline $1-4$ & $2,686,090$ & $3.3 \%$ & 6,052 & $15.5 \%$ & $2,692,142$ & $3.36 \%$ \\
\hline $5-99$ & $2,051,445$ & $16.6 \%$ & 101,799 & $43.0 \%$ & $2,153,244$ & $17.81 \%$ \\
\hline $100-999$ & 53,590 & $54.9 \%$ & 40,807 & $74.4 \%$ & 94,397 & $63.32 \%$ \\
\hline $1000+$ & 1,495 & $62.1 \%$ & 7,312 & $90.1 \%$ & 8,807 & $85.35 \%$ \\
\hline Total & $5,722,088$ & $8.2 \%$ & 159,087 & $51.7 \%$ & $5,881,175$ & $9.42 \%$ \\
\hline
\end{tabular}

Table 13.3

Types of plans found for matched employers, by firm size -1997

\begin{tabular}{lccc}
\hline Number of employees & Pension (\%) & Health (\%) & Other fringe (\%) \\
\hline $1-50$ & 87 & 2 & 24 \\
$51-100$ & 85 & 7 & 52 \\
$101-250$ & 86 & 28 & 55 \\
$251-750$ & 88 & 57 & 59 \\
$750+$ & 92 & 80 & 72 \\
Total & 87 & 7 & 30 \\
\hline
\end{tabular}


coverage but that we understate health coverage by even more than we would have expected. In our data for 1997, 61 percent of employees work for businesses that offer pension benefits, while 34 percent work for businesses that offer health benefits. BLS survey estimates from 2003 indicate that 57 percent of employees have access to retirement benefits. This figure excludes employees who have not met minimum length of service requirements and so would be expected to be somewhat below our estimate, which implicitly includes them. ${ }^{11}$

In contrast, a 1997 survey estimated that 86 percent of employees work for establishments that offer health benefits - more than twice our figure. ${ }^{12}$ We expect to understate health coverage somewhat given that certain small health plans are not required to file, but the difference seems too large for that to be the only problem. At the same time, we seem to find too much coverage under plans classified by sponsors as Fringe benefit plans on the Form 5500. This should include only Section 125 cafeteria plans (flexible benefit, reimbursement, and premium conversion plans) and non-jobrelated education benefit plans (under Section 127 of the tax code). We find that 36 percent of employees in 1997 work for firms offering plans classified in this way, while 1999 survey estimates imply that 28 percent of employees have access to Section 125 plans and only 10 percent have access to nonwork related educational assistance (and presumably there is considerable overlap in those types of benefits). Because we think that some health insurance plans may appear in the 5500 files as Fringe benefit plans, we start with estimates based on the more general question of whether an employer offers some form of fringe benefits, but we also examine how the estimates change when we look at a breakout of benefit types.

\subsubsection{Sample Characteristics}

While we match the 5500 data to Census's Business Register as a whole, most of our empirical work is based on the subset of those businesses for which we also have UI State data. In looking at employment growth we must also restrict our sample to firms continuing from 1997 to 2001. Before proceeding with our results, we briefly describe the differences in samples. While the 5500/BR data exists for all fifty-one states, the UI data restrict us to look at seven states. Thus, we have data for parts of firms that operate across multiple states, and no data for firms that operate only in other states, which leaves us as much as 1.8 million firms operating in 1997 and

11. It is difficult to put together a comparable total coverage number for pension benefits for either 1997 or 2001 for a couple of reasons. Prior to 1999, the BLS survey that collected data for benefits estimates (the Employee Benefit Survey) surveyed small and medium/large employers in alternating years. Beginning in 1999, BLS publishes estimates for all private employers, but access numbers are not available until 2003. The 2003 estimates are available at http://www.bls.gov/ncs/ebs/sp/ebbl0020.pdf

12. See http://www.meps.ahrq.gov/mepsweb/data_stats/summ_tables/insr/national/series_1/ 1997/tib2.pdf 
1.2 million firms operating in both 1997 and 2001 (Continuers). ${ }^{13}$ As explained in ALM, human-capital summary statistics are only created for firms with at least five employees, due to the difficulty of applying kernel density estimation techniques for calculating distributions to firms of very small sizes. Our regressions all make use of these wage decompositions, so we further restrict our sample to firms having at least five employees. This reduces the sample for 1997 to almost 400,000 and for the 1997/2001 Continuers sample to a little more than 300,000 . In addition, we do some of our productivity analyses on the subset of firms that also appear in the Annual Sample of Manufacturing (ASM) from which we derive measures of capital intensity. For 1997, this sample contained 10,263 firms.

Table 13.4 presents 1997 sample statistics for the seven-state 5500/BR/ UI data and the sample for which we also have $\mathrm{HC}$ estimates. ${ }^{14}$ Given that more than 50 percent of firms in the United States have less than five employees, the reduction in sample size from column 1 to 3 is dramatic. As expected, the sample without the small firms has on average older firms and a higher percentage of benefit-offering firms. The fraction of multi-unit firms is also higher.

The statistics for 1997/2001 continuers are fairly similar to the more comprehensive samples. The average firm labor productivity and mean firm wage effect for the sample of continuers (column [4]) is larger than for the sample that includes all the observations in 1997 (column [3]). The last row gives mean churning rates, which measure the rate of accessions and separations that occur at a firm over one quarter, above and beyond those needed to accomplish the firm's net growth during that period. ${ }^{15}$ Net growth is defined as total employment at the end of a quarter minus total employment at the beginning of the quarter and can be positive or negative. For firms with human capital estimates (i.e., at least five employees), the churning rates are similar for the 1997 firms and the continuers. For the entire sample, churning rates are lower for the continuers.

\subsection{Results}

\subsubsection{Evolution of the Human Capital Stock}

A firm that grows by one employee over a quarter may do so by simply hiring one more employee, or by hiring five new employees and letting four employees (new or old) go. The latter is likely to be more costly, but also

13. The unit of observation is generally a firm/state record; that is, a multi-unit firm that operates in several of the states for which we have data will have more than one record.

14. Table 13A.3 of the Appendix shows firm characteristics by benefit offer for the sample.

15. The formula used is $(|A+S|-|E-B|) /[(B+E) / 2]$, where $A=$ accessions, $S=$ separations, $B=$ employment at the beginning of the quarter, and $E=$ employment at the end of the quarter. 


\begin{tabular}{|c|c|c|c|c|}
\hline \multirow[b]{3}{*}{ Sample characteristics } & \multicolumn{4}{|c|}{ Data required } \\
\hline & \multicolumn{2}{|c|}{$5,500 / \mathrm{BR} / \mathrm{UI}$ data } & \multicolumn{2}{|c|}{$\begin{array}{l}5,500 / \mathrm{BR} / \mathrm{UI} \text { data } \\
\text { and } \mathrm{HC} \text { estimates }\end{array}$} \\
\hline & All 1997 & Continuers & All 1997 & Continuers \\
\hline Sample size & $1,860,072$ & $1,196,541$ & 390,635 & 302,079 \\
\hline Offer benefits in 1997 only & $5.44 \%$ & $4.29 \%$ & $10.52 \%$ & $7.76 \%$ \\
\hline Offer benefits in 2001 only & $1.94 \%$ & $2.83 \%$ & $3.53 \%$ & $4.44 \%$ \\
\hline Offer benefits in 1997 and 2001 & $9.68 \%$ & $13.76 \%$ & $21.27 \%$ & $26.61 \%$ \\
\hline Mean firm wage effect $\psi$ & - & - & -0.1049 & -0.0966 \\
\hline Multi-unit firm & $3.31 \%$ & $3.84 \%$ & $7.74 \%$ & $7.89 \%$ \\
\hline \multicolumn{5}{|l|}{ Firm age: } \\
\hline$<5$ years old & $31.88 \%$ & $28.15 \%$ & $21.64 \%$ & $18.66 \%$ \\
\hline 5 to $<10$ years old & $19.74 \%$ & $20.77 \%$ & $21.47 \%$ & $20.84 \%$ \\
\hline 10 to $<15$ years old & $13.58 \%$ & $15.33 \%$ & $17.49 \%$ & $18.04 \%$ \\
\hline 15 to $<20$ years old & $8.89 \%$ & $10.50 \%$ & $13.95 \%$ & $14.93 \%$ \\
\hline 20 or more years old & $14.11 \%$ & $16.75 \%$ & $25.45 \%$ & $27.53 \%$ \\
\hline \multicolumn{5}{|l|}{ Firm size: } \\
\hline$<5$ employees & $56.21 \%$ & $50.35 \%$ & - & - \\
\hline 5 to 99 employees & $41.12 \%$ & $46.43 \%$ & $92.18 \%$ & $92.07 \%$ \\
\hline 100 to 999 employees & $2.45 \%$ & $2.95 \%$ & $7.21 \%$ & $7.31 \%$ \\
\hline $1000+$ employees & $0.22 \%$ & $0.27 \%$ & $0.61 \%$ & $0.61 \%$ \\
\hline \multicolumn{5}{|l|}{ HC quartiles: } \\
\hline lowest & - & - & 27.10 & $26.92 \%$ \\
\hline highest & - & - & 25.75 & $25.88 \%$ \\
\hline \multicolumn{5}{|l|}{ Workers: } \\
\hline$\%$ prime age & $70.97 \%$ & $71.57 \%$ & $71.08 \%$ & $71.38 \%$ \\
\hline$\%$ female & $46.37 \%$ & $46.14 \%$ & $47.77 \%$ & $47.57 \%$ \\
\hline$\%$ foreign born & $19.04 \%$ & $18.70 \%$ & $16.78 \%$ & $16.64 \%$ \\
\hline$\%$ white, non-Hispanic & $71.65 \%$ & $72.23 \%$ & $71.26 \%$ & $71.82 \%$ \\
\hline \multicolumn{5}{|l|}{$\begin{array}{l}\text { Relative labor productivity: } \\
\text { deviation of log (productivity) }\end{array}$} \\
\hline from 2-digit SIC mean & - & - & 0.0461 & 0.0809 \\
\hline Churning rate (1st quarter, 1997) & 0.4063 & 0.3289 & 0.2886 & 0.2682 \\
\hline
\end{tabular}

Notes: The observations are on an EIN/state level. All variables are measured in 1997, except where noted otherwise.

makes possible more dramatic changes in the total skills embodied in the firm's workforce - for better or worse. While we do not do a formal decomposition, we do break our analysis into these two parts: churning and net growth. If a firm follows the first strategy of hiring and keeping one more person, then net growth is one person and churning is zero. If instead it hires five new employees and lets four go, churning is $8(=5+4-1)$ the number of extra employees who arrived or left above those needed to increase employment by one. We are interested in how both net growth and churning relate to benefit offering and how these two correlations might be different from each other. 


\section{Churning Regressions}

Existing work, based primarily on household data, has established that there is a strong negative association between rates of employee turnover and benefits. We present churning regressions here in part to confirm that this is true in our firm-based data as well, but also because our data allow us to address several unanswered questions. One advantage we have is that including the firm wage premium allows us to control for differences in other parts of firm compensation schemes. We also have richer measures of worker skill and more accurate measures of employer characteristics than are typically available from household survey data.

Table 13.5 presents the results from our analysis of churning rates for the first quarter of $1997 .{ }^{16}$ We exclude observations with churning rates of greater than 2 as likely to be subject to measurement error. Column (1) includes a dummy for whether or not the firm offered benefits in 1997 along with controls for the following firm characteristics: the wage premium or firm wage effect $(\psi)$, size, age, industry, state, and workforce demographic characteristics. In column (2) we add human capital characteristics, while columns (3) and (4) repeat those two specifications, but with more detailed benefit dummies.

In all specifications, benefits in general are negatively related to churning rates. In column (1), firms that currently offer benefits have about a 3 percentage point lower churning rate (in a sample with a mean churning rate of 28.9 percent). In column (2), adding human capital characteristics substantially reduces the size of the benefit coefficient, though it remains negative and significant. Thus, a substantial part of the negative association between benefits and churning is because businesses that employ workers with higher human capital levels are more likely to offer benefits and higher human capital levels are associated with reduced churning. Including dummies for specific benefit types in columns (3) and (4) in place of the general benefits dummy shows that the negative correlation with churning is common to all types of pensions plans and to health plans, but that DB and other (non-DC) pension plans have the most substantial and consistently negative associations with churning. A comparison of (3) and (4) shows that the negative association is reduced for all types of plans when the human capital measures are included, implying that an important component of the correlation found in (3) for all benefits is that more skilled (and higher paid) employees are more likely to be offered benefits.

We find somewhat odd results for firm size: churning rates are significantly higher for the 100 to 999 employee and 1000+ employee groups of firms than for the smallest category, though the largest category has slightly lower rates than the middle category. Note that we are controlling

16. We have estimated analogous regressions using churning measures from the 1 st quarter of 2001, and get very similar results so we have not presented them here. 
Table 13.5

Churning regressions: 1st quarter of 1997

\begin{tabular}{|c|c|c|c|c|}
\hline Independent variables & (1) & (2) & (3) & (4) \\
\hline Offered benefits in 1997 & $\begin{array}{c}-.0279 \\
(.0013)\end{array}$ & $\begin{array}{c}-.0045 \\
(.0012)\end{array}$ & - & - \\
\hline Offered DB pension plan in 1997 & - & - & $\begin{array}{l}-.0287 \\
(.0033)\end{array}$ & $\begin{array}{l}-.0185 \\
(.0032)\end{array}$ \\
\hline Offered DC pension plan in 1997 & - & - & $\begin{array}{l}-.0246 \\
(.0014)\end{array}$ & $\begin{array}{c}-.0031 \\
(.0014)\end{array}$ \\
\hline Offered other pension in 1997 & - & - & $\begin{array}{l}-.0400 \\
(.0061)\end{array}$ & $\begin{array}{l}-.0218 \\
(.0059)\end{array}$ \\
\hline Offered health plan in 1997 & - & - & $\begin{array}{l}-.0165 \\
(.0028)\end{array}$ & $\begin{array}{l}-.0083 \\
(.0027)\end{array}$ \\
\hline Offered other fringe plan in 1997 & - & - & $\begin{array}{l}-.0056 \\
(.0018)\end{array}$ & $\begin{array}{l}.0026 \\
(.0017)\end{array}$ \\
\hline Firm wage effect $(\psi)$ & $\begin{array}{c}-.1029 \\
(.0016)\end{array}$ & $\begin{array}{c}-.0842 \\
(.0017)\end{array}$ & $\begin{array}{l}-.1018 \\
(.0016)\end{array}$ & $\begin{array}{l}-.0838 \\
(.0017)\end{array}$ \\
\hline Multi-unit firm & $\begin{array}{l}.0299 \\
(.0022)\end{array}$ & $\begin{array}{l}.0173 \\
(.0021)\end{array}$ & $\begin{array}{l}.0313 \\
(.0022)\end{array}$ & $\begin{array}{l}.0178 \\
(.0021)\end{array}$ \\
\hline Firm age 5 to $<10$ & $\begin{array}{c}-.0703 \\
(.0016)\end{array}$ & $\begin{array}{c}-.0662 \\
(.0015)\end{array}$ & $\begin{array}{c}-.0705 \\
(.0016)\end{array}$ & $\begin{array}{l}-.0664 \\
(.0015)\end{array}$ \\
\hline Firm age 10 to $<15$ & $\begin{array}{l}-.0990 \\
(.0017)\end{array}$ & $\begin{array}{l}-.0914 \\
(.0016)\end{array}$ & $\begin{array}{l}-.0993 \\
(.0017)\end{array}$ & $\begin{array}{l}-.0915 \\
(.0016)\end{array}$ \\
\hline Firm age 15 to $<20$ & $\begin{array}{c}-.1206 \\
(.0018)\end{array}$ & $\begin{array}{c}-.1120 \\
(.0018)\end{array}$ & $\begin{array}{l}-.1204 \\
(.0018)\end{array}$ & $\begin{array}{c}-.1118 \\
(.0018)\end{array}$ \\
\hline Firm age 20 or more & $\begin{array}{l}-.1371 \\
(.0016)\end{array}$ & $\begin{array}{l}-.1312 \\
(.0016)\end{array}$ & $\begin{array}{l}-.1356 \\
(.0016)\end{array}$ & $\begin{array}{l}-.1304 \\
(.0016)\end{array}$ \\
\hline Firm size 100 to 999 employees & $\begin{array}{l}.0913 \\
(.0022)\end{array}$ & $\begin{array}{c}.0724 \\
(.0021)\end{array}$ & $\begin{array}{l}.0970 \\
(.0023)\end{array}$ & $\begin{array}{l}.0752 \\
(.0022)\end{array}$ \\
\hline Firm size $1000+$ employees & $\begin{array}{l}.0797 \\
(.0068)\end{array}$ & $\begin{array}{l}.0651 \\
(.0066)\end{array}$ & $\begin{array}{l}.0947 \\
(.0069)\end{array}$ & $\begin{array}{c}.0729 \\
(.0068)\end{array}$ \\
\hline$\%$ in lowest $\mathrm{HC}$ quartile & - & $\begin{array}{l}.1367 \\
(.0038)\end{array}$ & - & $\begin{array}{l}.1363 \\
(.0038)\end{array}$ \\
\hline$\%$ in highest $\mathrm{HC}$ quartile & - & $\begin{array}{l}-.1598 \\
(.0038)\end{array}$ & - & $\begin{array}{l}-.1594 \\
(.0038)\end{array}$ \\
\hline R-squared & .150 & .196 & 0.151 & 0.196 \\
\hline
\end{tabular}

Notes: $\mathrm{N}=390,635$. Dependent variable is the churning rate for the first quarter of 1997 , as defined in footnote 15; mean $=.289$. Sample is 1997 firms with churning rates of less than 2 . Regressions also include controls for state, two-digit industry, and worker demographics. All controls measured in 1997.

for firm age here, and the age effects are quite large, so it is not the case that large, well-established firms have higher churning rates than young, small firms. The fact that we are looking at churning over a very short period of time (one quarter) may contribute to this result, as small firms are much more likely to have a churning rate of zero in a quarter than is a firm with 1,000 employees.

One interesting result is that the inclusion of the human capital variables reduces the coefficient for DC plans much more than the coefficient for DB 
plans. This suggests that selection on the human capital characteristics that are consistently valued across employers (i.e., those captured by the individual fixed effects) is more important in explaining the lower turnover associated with DC plans than the turnover associated with DB plans. These results fit nicely with the pension literature's emphasis on the incentive effects of DB plans - high costs imposed on separations lead to reduced turnover - and with the observation that the similarly low turnover rates for DC plans probably have a different cause, namely selection effects.

\section{Firm Growth}

In table 13.6 we examine how firm growth is correlated with benefit provision. The sample consists of firms that were in existence in both 1997 and 2001. We regress the log difference in employment on benefits dummies, while controlling for characteristics of the firm and its workforce. In column (1) we simply control for whether a firm offers benefits in 1997, while in (2) we distinguish whether or not benefits are offered in 1997 only, in 2001 only, or in 1997 and 2001, leaving firms that offered benefits in neither year as the omitted category. In columns (3) and (4) we repeat these specifications with the addition of a control for labor productivity.

Overall, the continuers' sample has a negative growth rate: employment shrinks on average by about 4 percentage points over the period. Our regression results in columns (1) and (3) show that firms that offered benefits in 1997 grew more over the subsequent period than those that did not, conditional on surviving to 2001. Firms that offered benefits in both years grew substantially faster than those that offered them in neither: their growth rates were about 11 percentage points greater than the omitted category and that difference is significant. Changes in benefits are also correlated with firm growth, though it seems more likely that firms' choices to change their benefits were motivated by their growth experience than the converse. Firms that dropped benefits between 1997 and 2001 had growth rates that were on average about 3 percentage points lower than those of firms that did not offer benefits in either year in both columns (2) and (4). Firms that added benefits had growth rates that were about 25 percentage points higher than those for firms that offered benefits in neither year.

The other coefficients make clear that older firms and larger firms, unsurprisingly, grow more slowly. Firms with high churning rates also tend to grow more slowly. One might expect that, other characteristics constant, firms that are growing quickly would have high churning rates, as increasing the number of employees requires increasing the proportion with low tenure, and low tenure employees tend to have higher turnover rates. However, high turnover might also hamper desired firm growth. The negative coefficient suggests that the latter is likely the predominate effect.

The coefficients on the human capital measures indicate that employing many less-skilled workers is associated with lower growth rates. The coeffi- 
Table 13.6

Firm employment growth regressions

\begin{tabular}{|c|c|c|c|c|}
\hline Independent variables & (1) & (2) & (3) & (4) \\
\hline \multirow[t]{2}{*}{ Offered benefits in 1997} & .0470 & - & .0372 & - \\
\hline & $(.0026)$ & - & $(.0026)$ & - \\
\hline \multirow[t]{2}{*}{ Offered benefits in 1997 only } & - & -.0259 & - & -.0305 \\
\hline & - & $(.0041)$ & - & $(.0041)$ \\
\hline \multirow[t]{2}{*}{ Offered benefits in 2001 only } & - & .2612 & - & .2538 \\
\hline & - & $(.0052)$ & - & $(.0052)$ \\
\hline \multirow[t]{2}{*}{ Offered benefits in both years } & - & .1098 & - & .0982 \\
\hline & - & $(.0029)$ & - & $(.0029)$ \\
\hline \multirow[t]{2}{*}{ Firm wage effect $(\psi)$} & .1303 & .1098 & .0722 & .0566 \\
\hline & $(.0035)$ & $(.0035)$ & $(.0038)$ & $(.0038)$ \\
\hline \multirow[t]{2}{*}{ Multi-unit firm } & -.1917 & -.1975 & -.1928 & -.1984 \\
\hline & $(.0044)$ & $(.0044)$ & $(.0044)$ & $(.0044)$ \\
\hline \multirow[t]{2}{*}{ Firm age 5 to $<10$} & -.0724 & -.0701 & -.0741 & -.0717 \\
\hline & $(.0034)$ & $(.0034)$ & $(.0034)$ & $(.0034)$ \\
\hline \multirow{2}{*}{ Firm age 10 to $<15$} & -.0989 & -.0970 & -.1006 & -.0987 \\
\hline & $(.0035)$ & $(.0035)$ & $(.0035)$ & $(.0035)$ \\
\hline \multirow[t]{2}{*}{ Firm age 15 to $<20$} & -.1181 & -.1180 & -.1190 & -.1188 \\
\hline & $(.0038)$ & $(.0037)$ & $(.0038)$ & $(.0037)$ \\
\hline \multirow[t]{2}{*}{ Firm age 20 or more } & -.1381 & -.1410 & -.1392 & -.1419 \\
\hline & $(.0034)$ & $(.0034)$ & $(.0034)$ & $(.0034)$ \\
\hline \multirow[t]{2}{*}{ Firm size 100 to 999 employees } & -.0030 & -.0162 & -.0042 & -.0168 \\
\hline & $(.0045)$ & $(.0045)$ & $(.0045)$ & $(.0045)$ \\
\hline \multirow[t]{2}{*}{ Firm size $1000+$ employees } & -.0286 & -.0390 & -.0325 & -.0421 \\
\hline & $(.0140)$ & $(.0139)$ & $(.0139)$ & $(.0139)$ \\
\hline \multirow[t]{2}{*}{$\%$ in lowest $\mathrm{HC}$ quartile } & -.1550 & -.1372 & -.1134 & -.0990 \\
\hline & $(.0082)$ & $(.0082)$ & $(.0083)$ & $(.0082)$ \\
\hline \multirow{2}{*}{$\%$ in highest $\mathrm{HC}$ quartile } & .0675 & .0461 & .0018 & -.0140 \\
\hline & $(.0079)$ & $(.0079)$ & $(.0081)$ & $(.0080)$ \\
\hline \multirow[t]{2}{*}{ Churning rate (1st quarter, 1997) } & -.0641 & -0.0675 & -.0534 & -.0575 \\
\hline & $(.0036)$ & $(.0035)$ & $(.0036)$ & $(.0035)$ \\
\hline \multirow[t]{2}{*}{ Relative labor productivity (log) } & - & - & .0698 & .0647 \\
\hline & - & - & $(.0017)$ & $(.0017)$ \\
\hline R-squared & 0.0377 & 0.0485 & .0430 & .0531 \\
\hline
\end{tabular}

Notes: $\mathrm{N}=302,079$. Dependent variable is the log difference in employment: $\ln (\mathrm{Emp} 2001)$ $(\ln ($ Emp1997); mean $=-.04$. Sample is all firms continuing from 1997 to 2001 with churning rates $<2$. The regressions also include controls for state, two-digit industry, and worker demographic characteristics in 1997.

cient on the upper quartile measure is also consistent with a positive relationship between average human capital and firm growth, but the coefficients are much smaller. When we add the productivity measure in (3) and (4) this coefficient becomes insignificant and, in column (4), even negative so it appears that having high human capital employees is associated with greater firm growth only because it is associated with higher productivity. Once that is controlled for, the association is insignificant or negative, perhaps because of their cost.

The firm wage effect has a strong positive relationship with growth 
rates-firms that paid 10 percent more than the average had about 1.3 percentage point higher growth in column (1). This coefficient is also sensitive to the inclusion of productivity in the regressions. It is substantially smaller in columns (3) and (4), but remains positive. So higher paying firms grew faster over this period, in part because high productivity firms were growing faster, and high productivity and the firm component of pay are positively correlated.

For table 13.7 we substitute more detailed benefit dummies for the gen-

Table 13.7

Firm employment growth regressions with type of plan controls

\begin{tabular}{|c|c|c|}
\hline Independent variables & (1) & (2) \\
\hline Offered DB pension plan in 1997 & $\begin{array}{c}-.0619 \\
(.0065)\end{array}$ & $\begin{array}{c}-.0758 \\
(.0065)\end{array}$ \\
\hline Offered DC pension plan in 1997 & $\begin{array}{c}.0388 \\
(.0028)\end{array}$ & $\begin{array}{c}.0290 \\
(.0028)\end{array}$ \\
\hline Offered other pension in 1997 & $\begin{array}{l}.0852 \\
(.0119)\end{array}$ & $\begin{array}{c}.0787 \\
(.0118)\end{array}$ \\
\hline Offered health plan in 1997 & $\begin{array}{l}.0162 \\
(.0057)\end{array}$ & $\begin{array}{c}.0083 \\
(.0057)\end{array}$ \\
\hline Offered other fringe plan in 1997 & $\begin{array}{l}.0323 \\
(.0035)\end{array}$ & $\begin{array}{r}.0319 \\
(.0035)\end{array}$ \\
\hline Firm wage effect $(\psi)$ & $\begin{array}{l}.1311 \\
(.0035)\end{array}$ & $\begin{array}{c}.0728 \\
(.0038)\end{array}$ \\
\hline Multi-unit firm & $\begin{array}{l}-.1920 \\
(.0044)\end{array}$ & $\begin{array}{r}-.1924 \\
(.0044)\end{array}$ \\
\hline Firm age 5 to $<10$ & $\begin{array}{c}-.0723 \\
(.0034)\end{array}$ & $\begin{array}{c}-.0741 \\
(.0034)\end{array}$ \\
\hline Firm age 10 to $<15$ & $\begin{array}{c}-.0987 \\
(.0035)\end{array}$ & $\begin{array}{r}-.1005 \\
(.0035)\end{array}$ \\
\hline Firm age 15 to $<20$ & $\begin{array}{c}-.1173 \\
(.0038)\end{array}$ & $\begin{array}{r}-.1180 \\
(.0038)\end{array}$ \\
\hline Firm age 20 or more & $\begin{array}{c}-.1368 \\
(.0034)\end{array}$ & $\begin{array}{c}-.1372 \\
(.0034)\end{array}$ \\
\hline Firm size 100 to 999 employees & $\begin{array}{c}-.0077 \\
(.0047)\end{array}$ & $\begin{array}{c}-.0064 \\
(.0047)\end{array}$ \\
\hline Firm size $1000+$ employees & $\begin{array}{c}-.0314 \\
(.0143)\end{array}$ & $\begin{array}{r}-.0286 \\
(.0142)\end{array}$ \\
\hline$\%$ in lowest $\mathrm{HC}$ quartile & $\begin{array}{c}-.1542 \\
(.0082)\end{array}$ & $\begin{array}{r}-.1125 \\
(.0083)\end{array}$ \\
\hline$\%$ in highest $\mathrm{HC}$ quartile & $\begin{array}{c}.0703 \\
(.0079)\end{array}$ & $\begin{array}{c}.0044 \\
(.0081)\end{array}$ \\
\hline Churning rate (1st quarter, 1997) & $\begin{array}{c}-.0643 \\
(.0036)\end{array}$ & $\begin{array}{c}-.0537 \\
(.0036)\end{array}$ \\
\hline Relative labor productivity (log) & - & $\begin{array}{c}.0707 \\
(.0017)\end{array}$ \\
\hline R-squared & .038 & .044 \\
\hline
\end{tabular}

Notes: $\mathrm{N}=302,079$. Dependent variable is the log difference in employment; mean $=-.04$. Sample is all firms continuing from 1997 to 2001. The regressions include controls for state, two-digit SIC, and worker demographics. All control variables are measured as of 1997. 
eral benefit variable in table 13.6, columns (1) and (3). The coefficients on the control variables that are common to the two tables are very similar in the two tables. However, there are some striking differences in coefficients across different types of benefits. Firms that offered DB pension plans had employment losses that were significantly larger than those for firms without benefits. DB pensions plans are most typically offered by larger, older employers in more established parts of the economy (e.g., manufacturing), but we find this result even after controlling for age, size, and two-digit industry. Thus, offering a DB plan may be correlated with being in shrinking parts of the economy even within industry and age class. The other types of benefit plans are all positively associated with employment growth, with the largest coefficients for 'other' pension plans. Health plans have a positive but relatively small coefficient in column (1), which becomes insignificantly different from zero in column (2), where we control for productivity differences.

\subsubsection{Relationship to Productivity}

At this point, we do not have changes in productivity to use to directly examine the relationship between post-1997 productivity growth and benefit offering in 1997, so we instead look at the cross-sectional relationship. In table 13.8, the dependent variable is the log of labor productivity deviated from a two-digit industry-specific mean. The unit of observation is generally a firm/state record; that is, a multi-unit firm that operates in several of the states for which we have data will have more than one record. Some of the variables included are defined for the firm as a whole (whether or not benefits are offered, firm size, multi-unit status, and firm age), while the others are generally measured within state. ${ }^{17}$

Our primary interest is in the coefficient on the benefits indicator, which is positive and significant in each of our specifications. We recognize that several of our right-hand variables are likely endogenous, so the results should be interpreted simply as establishing correlations rather than causality. Because the dependent variable is a log difference, the coefficient on this variable in column 1 indicates that the productivity of firms that offer benefits is on average $.32 \log$ points (or roughly 38 percent) higher than that of nonbenefit-offering firms with similar characteristics. Given that benefits

17. The level of aggregation is important only for multi-unit firms that have diverse operations within a state. Because of the computational resources needed to estimate the wage decomposition, our decisions about how to handle aggregation issues are in part driven by the availability of estimates originally generated for other projects. The labor productivity and capital measures are calculated at a state/EIN/two-digit SIC level, and then a single two-digit SIC record is selected (if more than one exists) by taking the record with the highest payroll. The demographic and churning variables were handled similarly, except that the original measures were calculated at a state/EIN level. The human capital and firm effect variables are calculated at the state/EIN/two-digit SIC level. For these measures we use the observation with the highest employment because payroll is not available in these files. 
Table 13.8

1997 Productivity differentials associated with benefit offering

\begin{tabular}{|c|c|c|c|c|c|}
\hline Independent variables & (1) & (2) & (3) & (4) & (5) \\
\hline \multirow[t]{2}{*}{ Offers benefits in 1997} & .3218 & .2572 & .1488 & .0454 & .0481 \\
\hline & $(.0028)$ & $(.0027)$ & $(.0025)$ & $(.0144)$ & $(.0137)$ \\
\hline \multirow[t]{2}{*}{ Firm wage effect $(\psi)$} & - & - & .8277 & 1.0185 & .8279 \\
\hline & - & - & $(.0034)$ & $(.0321)$ & $(.0310)$ \\
\hline \multirow[t]{2}{*}{ Multi-unit firm } & .0111 & .0252 & .0214 & .0437 & .0269 \\
\hline & $(.0048)$ & $(.0046)$ & $(.0043)$ & $(.0187)$ & $(.0177)$ \\
\hline \multirow[t]{2}{*}{ Firm age 5 to $<10$} & .0342 & .0269 & .0385 & .1916 & .1732 \\
\hline & $(.0035)$ & $(.0034)$ & $(.0031)$ & $(.0257)$ & $(.0244)$ \\
\hline \multirow[t]{2}{*}{ Firm age 10 to $<15$} & .0517 & .0341 & .0415 & .1687 & .1250 \\
\hline & $(.0037)$ & $(.0036)$ & $(.0033)$ & $(.0241)$ & $(.0229)$ \\
\hline \multirow[t]{2}{*}{ Firm age 15 to $<20$} & .0647 & .0374 & .0349 & .1492 & .1050 \\
\hline & $(.0040)$ & $(.0039)$ & $(.0036)$ & $(.0248)$ & $(.0236)$ \\
\hline \multirow[t]{2}{*}{ Firm age 20 or more } & .0867 & .0501 & .0345 & .1579 & .0973 \\
\hline & $(.0036)$ & $(.0035)$ & $(.0033)$ & $(.0197)$ & $(.0188)$ \\
\hline \multirow[t]{2}{*}{ Firm size 100 to 999 employees } & .0157 & .0400 & .0152 & .1191 & .0881 \\
\hline & $(.0048)$ & $(.0047)$ & $(.0044)$ & $(.0158)$ & $(.0150)$ \\
\hline \multirow[t]{2}{*}{ Firm size $1000+$ employees } & .1102 & .1079 & .0612 & .1998 & .1242 \\
\hline & $(.0151)$ & $(.0146)$ & $(.0135)$ & $(.0345)$ & $(.0328)$ \\
\hline \multirow[t]{2}{*}{$\%$ in lowest $\mathrm{HC}$ quartile } & - & -.5360 & -.6111 & -.7937 & -.6171 \\
\hline & - & $(.0084)$ & $(.0078)$ & $(.0594)$ & $(.0566)$ \\
\hline \multirow[t]{2}{*}{$\%$ in highest $\mathrm{HC}$ quartile of } & - & .8372 & .9208 & .5223 & .4046 \\
\hline & - & $(.0082)$ & $(.0077)$ & $(.0530)$ & $(.0504)$ \\
\hline \multirow[t]{2}{*}{ Churning rate (1st quarter, 1997) } & - & - & -.1670 & -.1286 & -.1184 \\
\hline & - & - & $(.0033)$ & $(.0271)$ & $(.0257)$ \\
\hline \multirow[t]{2}{*}{$\log$ (capital intensity) } & - & - & - & - & .1899 \\
\hline & - & - & - & - & $(.0057)$ \\
\hline Sample & All & All & All & ASM & ASM \\
\hline $\mathrm{R}$-squared & 0.131 & 0.187 & 0.302 & 0.306 & 0.374 \\
\hline
\end{tabular}

Notes: $\mathrm{N}=390,635$ for overall sample; $\mathrm{N}=10,263$ for ASM sample. The dependent variable is the deviation of the log of labor productivity from two-digit SIC mean; mean $=.046$ for overall sample, $=.331$ for ASM sample. All columns also include controls for two-digit SIC, state, and worker demographics.

are costly, it would be difficult for benefit-offering firms to stay competitive if they did not have higher labor productivity, so this is reassuring.

In column (2), we add controls for the firm's distribution of worker human capital. The first human capital variable gives the percent of the workforce with a worker fixed-effect in the bottom quartile of the distribution; the second gives the percent in the top quartile. Both of these variables have large, significant coefficients of the expected sign — productivity rises with the fraction of workers in the more skilled parts of the distribution. Including these controls reduces the benefits coefficient by about .06 log points, indicating that about a fifth of the association between productivity and benefits found in the first column is explained by this fairly simple 
characterization of worker human capital. In all columns we control for differences in productivity associated with industry, firm size, firm age, state, and worker demographics. ${ }^{18}$ The coefficients on the firm size indicators are positive, significant, and generally increasing with size in the overall sample. Firms that are more than five years old have about 3 to 9 percent higher productivity in the overall sample, and about 10 to 19 percent higher productivity in manufacturing, but the differences between age groups among those older than five are generally not significant in manufacturing.

In the third column, we add the firm wage effect and a measure of workforce churning as additional controls. Across specifications, the churning measure has a negative coefficient that is usually significant, but whether or not it is included has little effect on the benefits coefficient. ${ }^{19}$ Adding the firm wage effect, however, reduces the benefits coefficient substantially. While firms that offer benefits have higher productivity, they also have compensation policies that pay what appear to be equivalent workers more than they receive in other jobs, and this component of pay has a very strong positive relationship to productivity, even when controlling for workforce composition.

The fourth and fifth columns present results for the subset of our overall sample that is included in the 1997 Annual Survey of Manufactures. This subsample is of interest because we can construct measures of capital that are not available outside manufacturing. ${ }^{20}$ Column (4) includes the same controls as column 3-it is included to illustrate changes in coefficients that are simply a result of the change in sample. The benefits coefficient is smaller in manufacturing, but in general the results do not look radically different. Adding our measure of capital - the log of capital per worker, based on the book value of capital divided by employment - has only a small effect on the benefits coefficient. Interestingly, it does reduce the size of the coefficients on the human capital, firm wage effect, and most demographic variables, so greater capital intensity does appear to account for some of the positive association found between worker skill and productivity.

Table 13.9 reports the results of the productivity regressions with detailed benefit type dummies in place of the overall dummy. While for the

18. We do not report the worker demographic coefficients in the tables to conserve space.

19. The order in which we introduce the human capital and firm effect controls has little impact on the portion of the reduction in the benefits coefficient that we attribute to the different controls.

20. We can construct capital measures for a larger sample of manufacturing firms by also including those that are in the 1997 Economic Census of Manufacturing (CM) but not in the ASM, which adds a lot of smaller firms. However, the ASM sample is asked more detailed capital questions, and imputation is used for some components of capital in non-ASM cases. We have run the same sets of regressions for both manufacturing samples, and while the coefficients are somewhat different, the general conclusions we draw are not. 


\begin{tabular}{|c|c|c|c|c|c|}
\hline Independent variables & (1) & (2) & (3) & (4) & (5) \\
\hline Offered DB pension plan in 1997 & $\begin{array}{c}.2981 \\
(.0072)\end{array}$ & $\begin{array}{c}.2608 \\
(.0070)\end{array}$ & $\begin{array}{l}.2011 \\
(.0065)\end{array}$ & $\begin{array}{l}.0976 \\
(.0211)\end{array}$ & $\begin{array}{c}.0699 \\
(.0201)\end{array}$ \\
\hline Offered DC pension plan in 1997 & $\begin{array}{c}.2976 \\
(.0030)\end{array}$ & $\begin{array}{c}.2367 \\
(.0030)\end{array}$ & $\begin{array}{l}.1434 \\
(.0028)\end{array}$ & $\begin{array}{l}.0223 \\
(.0153)\end{array}$ & $\begin{array}{c}.0282 \\
(.0146)\end{array}$ \\
\hline Offered other pension in 1997 & $\begin{array}{l}.2044 \\
(.0135)\end{array}$ & $\begin{array}{l}.1510 \\
(.0131)\end{array}$ & $\begin{array}{l}.0905 \\
(.0121)\end{array}$ & $\begin{array}{l}.0529 \\
(.0764)\end{array}$ & $\begin{array}{c}.0324 \\
(.0726)\end{array}$ \\
\hline Offered health plan in 1997 & $\begin{array}{c}.1348 \\
(.0062)\end{array}$ & $\begin{array}{c}.1372 \\
(.0060)\end{array}$ & $\begin{array}{c}.1070 \\
(.0056)\end{array}$ & $\begin{array}{c}.0336 \\
(.0187)\end{array}$ & $\begin{array}{c}.0160 \\
(.0178)\end{array}$ \\
\hline Offered other fringe plan in 1997 & $\begin{array}{c}.0556 \\
(.0039)\end{array}$ & $\begin{array}{c}.0418 \\
(.0037)\end{array}$ & $\begin{array}{l}.0071 \\
(.0035)\end{array}$ & $\begin{array}{l}-.0220 \\
(.0157)\end{array}$ & $\begin{array}{c}-.0160 \\
(.0149)\end{array}$ \\
\hline Firm wage effect $(\psi)$ & - & - & $\begin{array}{c}.8207 \\
(.0034)\end{array}$ & $\begin{array}{l}1.0009 \\
(.0322)\end{array}$ & $\begin{array}{c}.8187 \\
(.0311)\end{array}$ \\
\hline Multi-unit firm & $\begin{array}{c}-.0032 \\
(.0048)\end{array}$ & $\begin{array}{c}.0116 \\
(.0046)\end{array}$ & $\begin{array}{c}.0113 \\
(.0043)\end{array}$ & $\begin{array}{l}.0327 \\
(.0188)\end{array}$ & $\begin{array}{c}.0197 \\
(.0179)\end{array}$ \\
\hline Firm age 5 to $<10$ & $\begin{array}{c}.0371 \\
(.0035)\end{array}$ & $\begin{array}{c}.0294 \\
(.0033)\end{array}$ & $\begin{array}{c}.0399 \\
(.0031)\end{array}$ & $\begin{array}{c}.1998 \\
(0.256)\end{array}$ & $\begin{array}{c}.1802 \\
(.0244)\end{array}$ \\
\hline Firm age 10 to $<15$ & $\begin{array}{l}.0555 \\
(.0037)\end{array}$ & $\begin{array}{c}.0372 \\
(.0036)\end{array}$ & $\begin{array}{l}.0430 \\
(.0033)\end{array}$ & $\begin{array}{l}.1826 \\
(.0241)\end{array}$ & $\begin{array}{l}.1371 \\
(.0229)\end{array}$ \\
\hline Firm age 15 to $<20$ & $\begin{array}{c}.0637 \\
(.0040)\end{array}$ & $\begin{array}{c}.0361 \\
(.0039)\end{array}$ & $\begin{array}{c}.0327 \\
(.0036)\end{array}$ & $\begin{array}{c}.1630 \\
(.0247)\end{array}$ & $\begin{array}{c}.1175 \\
(.0235)\end{array}$ \\
\hline Firm age 20 or more & $\begin{array}{c}.0738 \\
(.0036)\end{array}$ & $\begin{array}{c}.0380 \\
(.0035)\end{array}$ & $\begin{array}{c}.0242 \\
(.0033)\end{array}$ & $\begin{array}{c}.1588 \\
(.0196)\end{array}$ & $\begin{array}{c}.1013 \\
(.0187)\end{array}$ \\
\hline Firm size 100 to 999 employees & $\begin{array}{c}-.0293 \\
(.0050)\end{array}$ & $\begin{array}{c}-.0042 \\
(.0049)\end{array}$ & $\begin{array}{l}-.0180 \\
(.0045)\end{array}$ & $\begin{array}{l}.1059 \\
(.0166)\end{array}$ & $\begin{array}{c}.0826 \\
(.0157)\end{array}$ \\
\hline Firm size $1000+$ employees & $\begin{array}{c}-.0150 \\
(.0153)\end{array}$ & $\begin{array}{c}-.0088 \\
(.0148)\end{array}$ & $\begin{array}{c}-.0253 \\
(.0137)\end{array}$ & $\begin{array}{l}.1682 \\
(.0355)\end{array}$ & $\begin{array}{c}.1067 \\
(.0338)\end{array}$ \\
\hline$\%$ in lowest $\mathrm{HC}$ quartile of & - & $\begin{array}{c}-.5314 \\
(.0084)\end{array}$ & $\begin{array}{l}-.6067 \\
(.0078)\end{array}$ & $\begin{array}{c}-.7864 \\
(.0594)\end{array}$ & $\begin{array}{c}-.6154 \\
(.0567)\end{array}$ \\
\hline$\%$ in highest $\mathrm{HC}$ quartile & - & $\begin{array}{c}.8294 \\
(.0082)\end{array}$ & $\begin{array}{c}.9125 \\
(.0077)\end{array}$ & $\begin{array}{l}.5185 \\
(.0530)\end{array}$ & $\begin{array}{c}.4042 \\
(.0505)\end{array}$ \\
\hline Churning rate (1st quarter, 1997) & - & - & $\begin{array}{l}-.1654 \\
(.0033)\end{array}$ & $\begin{array}{l}-.1258 \\
(.0271)\end{array}$ & $\begin{array}{l}-.1171 \\
(.0257)\end{array}$ \\
\hline Log(capital intensity) & - & - & - & - & $\begin{array}{c}.1884 \\
(.0057)\end{array}$ \\
\hline $\begin{array}{l}\text { Sample } \\
\text { R-squared }\end{array}$ & $\begin{array}{r}\text { All } \\
0.137\end{array}$ & $\begin{array}{r}\text { All } \\
0.192\end{array}$ & $\begin{array}{r}\text { All } \\
0.306\end{array}$ & $\begin{array}{l}\text { ASM } \\
0.308\end{array}$ & $\begin{array}{l}\text { ASM } \\
0.375\end{array}$ \\
\hline
\end{tabular}

Notes: $\mathrm{N}=390,635$ for overall sample; $\mathrm{N}=10,263$ for ASM sample. The dependent variable is the deviation of the $\log$ of labor productivity from two-digit SIC mean; mean $=.046$ for overall sample, $=.331$ for ASM sample. All columns also include controls for two-digit SIC, state, and worker demographics.

employment growth regressions the coefficients on the other control variables were little changed when we switched to detailed benefits controls, here we see one notable change between the two tables: the coefficients on the size dummies in the overall sample go from positive and significant to negative, though only occasionally significant. This seems likely due to larger, more productive firms in the overall sample offering more than one 
type of benefit or being more likely to offer the types of benefits most highly correlated with productivity.

The pension coefficients in table 13.9 are all positive and significant. Adding the human capital controls and then the churning rate and firm wage effect each reduces the size of the pension coefficients somewhat, but they all remain quite large in the general sample. Each type of pension is positively correlated with employee human capital and firm pay practices, and negatively correlated with turnover, which account for some but not all of their positive association with productivity. But it is interesting that the decreases are larger for the non-DB pension plans than for DB plans. As was the case with table 13.8, the estimated differences are smaller in manufacturing but they remain positive. The coefficients for offering health and fringe plans are positive and significant for the overall sample, but smaller than the pension coefficients. In manufacturing, the health plan coefficient loses its significance and the other fringe plan coefficient becomes negative, though not significantly so.

\subsubsection{Hazard Estimates of Firm Failure}

Do firms that currently offer benefits have higher future survival rates, conditioning on other observable characteristics? Why might there be such a relationship? Including benefits as part of compensation is correlated with having a more stable workforce, and a more stable workforce may reduce the likelihood that a firm goes out of business. However, if benefits are of more value to employees when they expect their current employer to stay in business, or if an employer's gain to offering benefits accrues over a long period of time, then employers who are less likely to stay in business may also be less likely to offer benefits. At this point, little is known about whether such a relationship even exists, so our goal here is simply to describe the empirical relationship rather than to establish causality. We do so using our complete sample of firms in existence in 1997 and exploiting their rates of failure over the 1997 to 2003 period. A firm is measured as having failed if it stops filing the UI records that underlie our human capital estimates. To examine this relationship, we use a Cox proportional hazard model to estimate the probability of a firm failing in the years after 1997, conditional on surviving until 1997, and include a dummy variable for having offered benefits in $1997 .{ }^{21}$ In addition to benefits, in all specifications we also include controls for firm age, industry, state, multi-unit status, firm size, and workforce demographics. We measure all of these explanatory variables as of 1997 . While alternative functional forms could be used here - for example, a probit — the hazard model takes advantage of

21. By using a conditional probability function, the Cox proportional hazard method controls for left truncation/delayed entry (firms are first observed in 1997, but were already in business before). Only observations from 1997 and onward are used in calculating the loglikelihood function. 
variation in the timing of failure as well as whether or not a failure occurred at some point in the six year period for which we have data.

We present four sets of estimates: tables 13.10 and 13.11 give results for the overall sample, first using the general benefits dummy (13.10) and then using dummies for plan type (13.11). In tables 13.12 and 13.13, we restrict our sample to firms with at least 100 employees. Recall that for some types of benefits (primarily health plans) sponsors are not required to file a Form 5500 if the plan has fewer than 100 enrollees, and thus we measure benefits coverage less accurately for smaller firms, which are excluded in these tables. The specifications (2), (3), and (4) for each table differ from (1) in that we progressively add the human capital quartile measures and the firm wage effect $(\psi)$, the churning measure, and then labor productivity.

In all specifications in tables 13.10 and 13.11 , we find a significant nega-

Table 13.10 Hazard estimates of the relationship between firm death and benefit offering: All firms, 1997-2003

\begin{tabular}{lcccc}
\hline Independent variables & $(1)$ & $(2)$ & $(3)$ & $(4)$ \\
\hline Offers benefit in 1997 & -.2315 & -.2084 & -.2068 & -.1853 \\
& $(.0077)$ & $(.0079)$ & $(.0079)$ & $(.0079)$ \\
Firm wage effect $(\Psi)$ & - & .0448 & .0747 & .2009 \\
& - & $(.0098$ & $(.0100)$ & $(.0110)$ \\
Multi-unit firm & -.0227 & -.0288 & -.0314 & -.0281 \\
& $(.0128)$ & $(.0128)$ & $(.0127)$ & $(.0127)$ \\
Firm age 5 to $<10$ & -.4595 & -.4579 & -.4504 & -.4492 \\
& $(.0118)$ & $(.0118)$ & $(.0118)$ & $(.0118)$ \\
Firm age 10 to $<15$ & -.8975 & -.8942 & -.8834 & -.8835 \\
& $(.0189)$ & $. .0189)$ & $(.0189)$ & $(.0189)$ \\
Firm age 15 to $<20$ & -1.4074 & -1.4021 & -1.3883 & -1.3910 \\
& $(.0266)$ & $. .0266)$ & $. .0266)$ & $(.0266)$ \\
Firm age 20 or more & -1.6950 & -1.6912 & -1.6744 & -1.6719 \\
& $(.0321)$ & $(.0321)$ & $. .0321)$ & $(.0321)$ \\
Firm size 100 to 999 employees & .1985 & .1817 & .1559 & .1550 \\
& $(.0125)$ & $(.0126)$ & $(.0125)$ & $(.0126)$ \\
Firm size 1000+ employees & .1926 & .1839 & .1599 & .1663 \\
& $(.0403)$ & $(.0403)$ & $(.0404)$ & $(.0405)$ \\
\% in lowest HC quartile & - & .0706 & .0326 & -.0598 \\
& - & $(.0213)$ & $(.0215)$ & $(.0218)$ \\
\% in highest HC quartile & - & -.4806 & -.4314 & -.2973 \\
Churning rate (1st quarter, 1997) & - & $(.0235)$ & $(.0236)$ & $(.0241)$ \\
& - & - & .2838 & .2591 \\
Relative labor productivity $(\log )$ & - & - & $(.0083)$ & $(.0084)$ \\
& - & - & - & -.1482 \\
& - & - & - & $(.0051)$ \\
\hline
\end{tabular}

Notes: Number of EIN/State observations $=389,051$. Number of failures $=107,652$. Hazards also include controls for state, two-digit SIC, and workforce demographic characteristics. All controls are measured in 1997. 
Table 13.11

Hazard estimates with plan type controls: All firms, 1997-2003

\begin{tabular}{|c|c|c|c|c|}
\hline Independent variables & (1) & (2) & (3) & (4) \\
\hline Offered DB pension plan in 1997 & $\begin{array}{l}-.0888 \\
(.0215)\end{array}$ & $\begin{array}{l}-.0750 \\
(.0216)\end{array}$ & $\begin{array}{c}-.0686 \\
(.0216)\end{array}$ & $\begin{array}{c}-.0383 \\
(.0216)\end{array}$ \\
\hline Offered DC pension plan in 1997 & $\begin{array}{l}-.2465 \\
(.0086)\end{array}$ & $\begin{array}{c}-.2213 \\
(.0088)\end{array}$ & $\begin{array}{l}-.2208 \\
(.0088)\end{array}$ & $\begin{array}{l}-.1989 \\
(.0088)\end{array}$ \\
\hline Offered other pension in 1997 & $\begin{array}{l}-.4586 \\
(.0490)\end{array}$ & $\begin{array}{l}-.4400 \\
(.0490)\end{array}$ & $\begin{array}{l}-.4317 \\
(.0489)\end{array}$ & $\begin{array}{l}-.4220 \\
(.0489)\end{array}$ \\
\hline Offered health plan in 1997 & $\begin{array}{l}.3268 \\
(.0167)\end{array}$ & $\begin{array}{l}.3232 \\
(.0167)\end{array}$ & $\begin{array}{l}.3283 \\
(.0167)\end{array}$ & $\begin{array}{l}.3410 \\
(.0167)\end{array}$ \\
\hline Offered other fringe plan in 1997 & $\begin{array}{l}-.0471 \\
(.0108)\end{array}$ & $\begin{array}{l}-.0431 \\
(.0108)\end{array}$ & $\begin{array}{l}-.0432 \\
(.0108)\end{array}$ & $\begin{array}{l}-.0409 \\
(.0108)\end{array}$ \\
\hline Firm wage effect $(\psi)$ & - & $\begin{array}{l}.0353 \\
(.0098)\end{array}$ & $\begin{array}{l}.0651 \\
(.0100)\end{array}$ & $\begin{array}{l}.1931 \\
(.0110)\end{array}$ \\
\hline Multi-unit firm & $\begin{array}{l}-.0352 \\
(.0128)\end{array}$ & $\begin{array}{l}-.0416 \\
(.0128)\end{array}$ & $\begin{array}{l}-.0447 \\
(.0128)\end{array}$ & $\begin{array}{l}-.0425 \\
(.0128)\end{array}$ \\
\hline Firm age 5 to $<10$ & $\begin{array}{c}-.4615 \\
(.0118)\end{array}$ & $\begin{array}{c}-.4599 \\
(.0118)\end{array}$ & $\begin{array}{l}-.4523 \\
(.0118)\end{array}$ & $\begin{array}{c}-.4511 \\
(.0118)\end{array}$ \\
\hline Firm age 10 to $<15$ & $\begin{array}{l}-.9011 \\
(.0189)\end{array}$ & $\begin{array}{l}-.8977 \\
(.0189)\end{array}$ & $\begin{array}{c}-.8869 \\
(.0189)\end{array}$ & $\begin{array}{l}-.8871 \\
(.0189)\end{array}$ \\
\hline Firm age 15 to $<20$ & $\begin{array}{r}-1.4119 \\
(.0266)\end{array}$ & $\begin{array}{r}-1.4065 \\
(.0266)\end{array}$ & $\begin{array}{r}-1.3928 \\
(.0266)\end{array}$ & $\begin{array}{r}-1.396 \\
\quad(.0266)\end{array}$ \\
\hline Firm age 20 or more & $\begin{array}{r}-1.7193 \\
(.0322)\end{array}$ & $\begin{array}{r}-1.7161 \\
(.0321)\end{array}$ & $\begin{array}{r}-1.7003 \\
(.0321)\end{array}$ & $\begin{array}{r}-1.7002 \\
\quad(.0322)\end{array}$ \\
\hline Firm size 100 to 999 employees & $\begin{array}{l}.1260 \\
(.0133)\end{array}$ & $\begin{array}{l}.1105 \\
(.0133)\end{array}$ & $\begin{array}{l}.0844 \\
(.0133)\end{array}$ & $\begin{array}{l}.0797 \\
(.0133)\end{array}$ \\
\hline Firm size $1000+$ employees & $\begin{array}{l}.0842 \\
(.0415)\end{array}$ & $\begin{array}{l}.0755 \\
(.0415)\end{array}$ & $\begin{array}{l}.0485 \\
(.0414)\end{array}$ & $\begin{array}{l}.0431 \\
(.0416)\end{array}$ \\
\hline$\%$ in lowest $\mathrm{HC}$ quartile & - & $\begin{array}{l}.0838 \\
(.0214)\end{array}$ & $\begin{array}{l}.0458 \\
(.0216)\end{array}$ & $\begin{array}{l}-.0478 \\
(.0241)\end{array}$ \\
\hline$\%$ in highest $\mathrm{HC}$ quartile & - & $\begin{array}{l}-.4807 \\
(.0236)\end{array}$ & $\begin{array}{l}-.4314 \\
(.0237)\end{array}$ & $\begin{array}{l}-.2958 \\
(.0241)\end{array}$ \\
\hline Churning rate (1st quarter, 1997) & - & - & $\begin{array}{l}.2853 \\
(.0083)\end{array}$ & $\begin{array}{l}.2603 \\
(.0084)\end{array}$ \\
\hline Relative labor productivity (log) & - & - & - & $\begin{array}{l}-.1514 \\
(.0051)\end{array}$ \\
\hline
\end{tabular}

Notes: Number of EIN/State observations $=388,814$. Number of failures $=107,583$. Hazards also include controls for state, two-digit SIC, and workforce demographics. All controls are measured in 1997.

tive relationship between the likelihood of post-1997 firm failure and the provision of benefits, with the notable exception of health insurance. The coefficients on the overall benefit dummy in table 13.10 indicate that the hazard of firm death is on average roughly 20 percent lower for firms that provide benefits, with the size of the relationship somewhat smaller in specifications with additional controls. In 13.11 where we examine different types of benefits we find similarly sized coefficients for DC pension plans, and even larger ones for other (i.e., non-DC/non-DB) pensions. The DB 
Table 13.12

Hazard estimates of firm death and benefit offering: Firms with 100 or more employees, 1997-2003

\begin{tabular}{lcccc}
\hline Independent variables & $(1)$ & $(2)$ & $(3)$ & $(4)$ \\
\hline Offers benefit in 1997 & -.2708 & -.2887 & -.2820 & -.2808 \\
& $(.0234)$ & $(.0236)$ & $(.0236)$ & $(.0236)$ \\
Firm wage effect $(\psi)$ & - & .4665 & .5348 & .6778 \\
& - & $(.0631)$ & $. .0647)$ & $(.0704)$ \\
Multi-unit firm & -.0089 & -.0105 & -.0085 & -.0035 \\
& $(.0247)$ & $(.0247)$ & $. .0247)$ & $(.0248)$ \\
Firm age 5 to $<10$ & -.3748 & -.3730 & -.3656 & -.3607 \\
& $(.0617)$ & $(.0617)$ & $. .0618)$ & $(.0617)$ \\
Firm age 10 to $<15$ & -.7543 & -.7511 & -.7353 & -.7304 \\
& $(.0863)$ & $(.0863)$ & $(.0863)$ & $(.0863)$ \\
Firm age 15 to $<20$ & -1.4061 & -1.4056 & -1.3852 & -1.3838 \\
& $(.1108)$ & $(.1108)$ & $(.1109)$ & $(.1109)$ \\
Firm age 20 or more & -1.6064 & -1.6151 & -1.5912 & -1.5895 \\
& $(.1189)$ & $(.1190)$ & $(.1191)$ & $(.1190)$ \\
Firm size $1000+$ employees & -.0807 & -.0985 & -.1005 & -.0977 \\
& $(.0425)$ & $(.0429)$ & $(.0429)$ & $(.0429)$ \\
\% in lowest HC quartile & - & .0607 & -.0223 & -.1030 \\
& - & $(.1215)$ & $(.1228)$ & $(.1233)$ \\
\% in highest HC quartile & - & .1464 & .1554 & .2299 \\
& - & $(.1051)$ & $(.1052)$ & $(.1057)$ \\
Churning rate (1st quarter, 1997) & - & - & .2419 & .2168 \\
& - & - & $(.0394)$ & $(.0397)$ \\
Relative labor productivity $(\log )$ & - & - & - & -.1092 \\
& - & - & - & $(.0177)$ \\
\hline
\end{tabular}

Notes: Number of EIN/State observations $=30,191$. Number of failures $=8,498$. Hazards also include controls for state, two-digit SIC, and workforce demographic characteristics. All controls are measured in 1997.

plans and other fringe plans have smaller but still negative and generally significant coefficients. Health plans, however, have large positive coefficients, indicating that on average firms that are matched to a health plan have about a 33 percent higher failure rate than similar firms that do not match to such a plan.

In table 13.12, where we restrict our sample to firms with 100 or more employees, the overall benefit dummy coefficients remain negative and significant, and increase slightly in magnitude. Similar comments apply to the coefficients on detailed benefit types in table 13.13-there are no changes in sign and the coefficients often (though not always) increase in magnitude, but again with the notable exception of health plans. The health plan coefficients remain positive, but drop dramatically in size to imply only a five to six percent higher hazard rate for firms that offer health plans. Thus, it is mostly among small firms that we find dramatically higher failure rates for firms that match to a Form 5500 health plan. Particularly with health 
Table 13.13

Hazard estimates with plan type controls: Firms with $100+$ employees, 1997-2003

\begin{tabular}{|c|c|c|c|c|}
\hline Independent variables & (1) & (2) & (3) & (4) \\
\hline Offered DB pension plan in 1997 & $\begin{array}{c}-.1113 \\
(.0384)\end{array}$ & $\begin{array}{c}-.1311 \\
(.0386)\end{array}$ & $\begin{array}{l}-.1309 \\
(.0386)\end{array}$ & $\begin{array}{l}-.1199 \\
(.0387)\end{array}$ \\
\hline Offered DC pension plan in 1997 & $\begin{array}{c}-.2037 \\
(.0259)\end{array}$ & $\begin{array}{c}-.2128 \\
(.0259)\end{array}$ & $\begin{array}{l}-.2112 \\
(.0260)\end{array}$ & $\begin{array}{l}-.2117 \\
(.0260)\end{array}$ \\
\hline Offered other pension in 1997 & $\begin{array}{c}-.5753 \\
(.0955)\end{array}$ & $\begin{array}{c}-.5774 \\
(.0955)\end{array}$ & $\begin{array}{l}-.5716 \\
(.0956)\end{array}$ & $\begin{array}{l}-.5705 \\
(.0955)\end{array}$ \\
\hline Offered health plan in 1997 & $\begin{array}{l}.0633 \\
(.0273)\end{array}$ & $\begin{array}{l}.0479 \\
(.0274)\end{array}$ & $\begin{array}{l}.0539 \\
(.0275)\end{array}$ & $\begin{array}{l}.0549 \\
(.0275)\end{array}$ \\
\hline Offered other fringe plan in 1997 & $\begin{array}{c}-.1164 \\
(.0251)\end{array}$ & $\begin{array}{c}-.1190 \\
(.0251)\end{array}$ & $\begin{array}{l}-.1179 \\
(.0251)\end{array}$ & $\begin{array}{l}-.1167 \\
(.0251)\end{array}$ \\
\hline Firm wage effect $(\psi)$ & - & $\begin{array}{c}.4715 \\
(.0639)\end{array}$ & $\begin{array}{c}.5403 \\
(.0654)\end{array}$ & $\begin{array}{c}.6764 \\
(.0710)\end{array}$ \\
\hline Multi-unit firm & $\begin{array}{l}-.0090 \\
(.0248)\end{array}$ & $\begin{array}{c}-.0088 \\
(.0248)\end{array}$ & $\begin{array}{c}-.0071 \\
(.0248)\end{array}$ & $\begin{array}{l}-.0029 \\
(.0248)\end{array}$ \\
\hline Firm age 5 to $<10$ & $\begin{array}{l}-.3865 \\
(.0618)\end{array}$ & $\begin{array}{c}-.3848 \\
(.0618)\end{array}$ & $\begin{array}{c}-.3772 \\
(.0619)\end{array}$ & $\begin{array}{c}-.3724 \\
(.0618)\end{array}$ \\
\hline Firm age 10 to $<15$ & $\begin{array}{c}-.7653 \\
(.0864)\end{array}$ & $\begin{array}{c}-.7625 \\
(.0865)\end{array}$ & $\begin{array}{l}-.7469 \\
(.0865)\end{array}$ & $\begin{array}{l}-.7417 \\
(.0865)\end{array}$ \\
\hline Firm age 15 to $<20$ & $\begin{array}{r}-1.4137 \\
(.1110)\end{array}$ & $\begin{array}{r}-1.4131 \\
(.1110)\end{array}$ & $\begin{array}{r}-1.3927 \\
(.1111)\end{array}$ & $\begin{array}{r}-1.3908 \\
\quad(.1111)\end{array}$ \\
\hline Firm age 20 or more & $\begin{array}{r}-1.6020 \\
(.1192)\end{array}$ & $\begin{array}{r}-1.6080 \\
(.1192)\end{array}$ & $\begin{array}{r}-1.5845 \\
(.1193)\end{array}$ & $\begin{array}{r}-1.5836 \\
(.1192)\end{array}$ \\
\hline Firm size $1000+$ employees & $\begin{array}{c}-.0593 \\
(.0431)\end{array}$ & $\begin{array}{c}-.0729 \\
(.0434)\end{array}$ & $\begin{array}{l}-.0758 \\
(.0434)\end{array}$ & $\begin{array}{c}-.0745 \\
(.0434)\end{array}$ \\
\hline$\%$ in lowest $\mathrm{HC}$ quartile & - & $\begin{array}{l}.0587 \\
(.1217)\end{array}$ & $\begin{array}{l}-.0255 \\
(.1229)\end{array}$ & $\begin{array}{l}-.1014 \\
(.1234)\end{array}$ \\
\hline$\%$ in highest $\mathrm{HC}$ quartile & - & $\begin{array}{l}.1806 \\
(.1053)\end{array}$ & $\begin{array}{l}.1896 \\
(.1054)\end{array}$ & $\begin{array}{l}.2587 \\
(.1059)\end{array}$ \\
\hline Churning rate (1st quarter, 1997) & - & - & $\begin{array}{l}.2453 \\
(.0395)\end{array}$ & $\begin{array}{l}.2215 \\
(.0397)\end{array}$ \\
\hline Relative labor productivity (log) & - & - & - & $\begin{array}{l}-.1047 \\
(.0178)\end{array}$ \\
\hline
\end{tabular}

Notes: Number of EIN/State observations $=30,129$. Number of failures $=8,476$. Hazards also include controls for state, two-digit SIC, and workforce demographics. All controls are measured in 1997.

plans, the difference in results between the two samples may be an artifact of filing rules. Recall that for small health plans, only plans that are at least partially self-insured must file. While the majority of self-insured plans use stop-loss coverage to limit their financial risk, it must still be a fairly risky strategy for small firms to forgo full insurance when providing health benefits. If firms that choose risky strategies in providing benefits are also more likely to take risks in other areas, it may not be surprising that they would be more likely to fail, particularly when the comparison group must include some firms that offer health insurance but fully insure. 
Still, even among the large sample, we find a positive association between health insurance offering and failure, conditioning on all of the other variables in the regressions. This indicates that it is not only differences in filing requirements that make health insurance appear so different from the other types of benefits. We can only hypothesize why this might be so. One possibility is that firms have more flexibility in offering pension plans (at least non-DB plans) when they are doing well and dropping them when business is poor because employees care less about the consistency of current pension coverage than of health coverage. A very generous plan this year and none the next may be equivalent to a meager plan both years to the average worker because they provide the same stream of future consumption. The same is not true for health plans, which may make it more difficult for firms to cut health insurance in lean times, and might in turn lead to a much more negative coefficient in hazard regressions for pension plans than for health plans. However, it is not clear that this could generate a positive coefficient for health plans, which is in fact what we find.

Unsurprisingly, firm age has a large and consistently negative association with the likelihood of failure, but our size effects are puzzling. We actually find lower rates of failure for firms with fewer than 100 employees than for larger firms in the specifications in tables 13.10 and 13.11, though the differences between medium sized (100 to 999) and very large employers $(1000+)$ look more reasonable. The largest firms have either similar (in table 13.10) or lower rates of failure (tables 13.11, 13.12, and 13.13), depending on the specification. Note that the differences in hazard rates are much larger for age than for size. If we do not include age controls, the size coefficients follow the expected pattern - they are negative and increase in magnitude with size.

The human capital measures have less consistent effects. In the overall sample, with either specification of benefits controls, firms with more skilled workers generally have higher survival rates, though adding productivity as a control reduces the size of the effects. However, in the sample with only larger firms, the effects are not significant and the coefficients vary somewhat in sign. With churning and labor productivity controls in the hazard, the coefficient on the upper quartile of the human capital distribution in 13.13 is positive and marginally significant, implying a higher rate of failure among firms that employ a higher proportion of skilled workers, perhaps because of their cost.

The firm wage effect, which captures firm pay differentials, has a positive effect in all specifications, but for the overall sample the effect is quite small unless we control for labor productivity. Interestingly, the difference in the size of the coefficients on the firm wage effect in columns (2) and (3) between tables $13.10,13.11,13.12$, and 13.13 suggests that it is only among small firms that those with higher average pay have high enough labor productivity that they are less likely to fail. For both samples, controlling for 
labor productivity results in a large positive coefficient on the firm wage effect: holding productivity, turnover, and workforce characteristics constant, higher average pay is associated with higher rates of failure. Reassuringly, labor productivity has a strong negative correlation with the probability of failure wherever we include it, while higher churning rates are positively related to failure rates, as we would expect.

\subsection{Summary}

Using Form 5500 data combined with LEHD integrated UI data for 1997 to 2003, we find that firms that offer benefits have lower turnover rates and grow faster than the average non-benefit-offering firm. We examine different types of benefits, and find the same general pattern for most types of plans, with the exception of defined benefit pension plans for which we find lower turnover but slower employment growth. Controlling for workforce human capital characteristics reduces the estimated effects but does not eliminate them. Firms that add benefits over this period have particularly high rates of employment growth, suggesting that significant employment growth may be a factor in the decision to offer benefits for firms that do not already do so.

In our analysis of productivity differences across firms, we find that both benefits and the firm-specific component of pay are positively related to productivity. We also find that firms that offer benefits are less likely to fail - even after controlling for other observable characteristics - than are firms that do not offer benefits. Many interpretations could be put on this. One is that of endogeneity-firms that are more likely to die (either due to current financial problems, or perhaps because they are an inherently more risky business) are less likely to offer benefits. This could either be as a way to cut down on current costs, or because workers value benefits less when the risk of future default is higher.

In general, our findings verify that there is a correlation between a firm's decision to offer benefits and the mobility and productivity of its labor force as well as the firm's length of life. While our results do not confirm a causal relationship between benefits and firm outcomes, they do highlight the importance of considering both benefits and wages when studying the labor market decisions made by firms and workers. 


\section{Appendix}

Table 13A.1

Distribution of 5500 plan records by exclusive type

\begin{tabular}{lrr}
\hline Exclusive benefit plan types & Number & Percent (\%) \\
\hline Defined benefit plan & 64,313 & 6.00 \\
Defined contribution plan & 657,324 & 61.30 \\
Other pension plan & 24,916 & 2.30 \\
Health plan & 65,333 & 6.10 \\
Fringe benefit plan & 208,469 & 19.40 \\
Welfare and fringe benefit plan & 42,851 & 4.00 \\
Welfare and pension benefit plan & 2,915 & 0.30 \\
No info on plan benefit type & 5,899 & 0.60 \\
Total & $1,072,020$ & 100.00 \\
\hline
\end{tabular}

Table 13A.2

Business register match rates, weighted by employment-1997 and 2001

\begin{tabular}{|c|c|c|c|c|c|c|}
\hline \multirow[b]{2}{*}{$\begin{array}{l}\text { Number of } \\
\text { employees }\end{array}$} & \multicolumn{2}{|c|}{ Single units } & \multicolumn{2}{|c|}{ Multi-units } & \multicolumn{2}{|c|}{ All Firms } \\
\hline & $\begin{array}{c}\text { Total } \\
\text { employment }\end{array}$ & $\begin{array}{c}\text { Match } \\
\text { rate }(\%)\end{array}$ & $\begin{array}{c}\text { Total } \\
\text { employment }\end{array}$ & $\begin{array}{c}\text { Match } \\
\text { rate }(\%)\end{array}$ & $\begin{array}{c}\text { Total } \\
\text { employment }\end{array}$ & $\begin{array}{r}\text { Match } \\
\text { rate }(\%)\end{array}$ \\
\hline & & & А. 1997 & & & \\
\hline 1 to 4 & $5,500,708$ & 5.2 & 22,244 & 16.2 & $5,522,952$ & 5.2 \\
\hline 5 to 99 & $28,665,996$ & 29.5 & $4,590,771$ & 57.1 & $33,256,767$ & 33.3 \\
\hline 100 to 999 & $8,987,671$ & 64.1 & $12,237,687$ & 82.0 & $21,225,358$ & 74.4 \\
\hline $1000+$ & $2,366,799$ & 69.5 & $43,297,297$ & 95.5 & $45,664,096$ & 94.1 \\
\hline Total & $45,521,174$ & 35.5 & $60,147,999$ & 89.8 & $105,669,173$ & 66.4 \\
\hline & & & B. 2001 & & & \\
\hline 1 to 4 & $5,604,584$ & 4.2 & 17,668 & 16.0 & $5,622,252$ & 4.2 \\
\hline 5 to 99 & $31,793,403$ & 25.3 & $3,560,992$ & 51.7 & $35,354,395$ & 27.9 \\
\hline 100 to 999 & $10,855,284$ & 56.9 & $11,596,094$ & 78.1 & $22,451,378$ & 67.9 \\
\hline $1000+$ & $3,829,941$ & 53.1 & $51,039,833$ & 94.5 & $54,869,774$ & 91.6 \\
\hline Total & $52,083,212$ & 31.6 & $66,214,587$ & 89.3 & $118,297,799$ & 63.9 \\
\hline
\end{tabular}


Table 13A.3

Firm characteristics by benefit offer-1997

\begin{tabular}{|c|c|c|}
\hline & Benefit-providing firms & Non-benefit-providing firms \\
\hline Sample size & 124,188 & 266,447 \\
\hline Mean firm wage effect $\psi$ & 0.0656 & -0.1844 \\
\hline Multi-unit firm & $13.11 \%$ & $5.24 \%$ \\
\hline \multicolumn{3}{|l|}{ Firm age: } \\
\hline$<5$ years old & $9.79 \%$ & $27.17 \%$ \\
\hline 5 to $<10$ years old & $14.73 \%$ & $24.60 \%$ \\
\hline 10 to $<15$ years old & $16.78 \%$ & $17.82 \%$ \\
\hline 15 to $<20$ years old & $18.02 \%$ & $12.06 \%$ \\
\hline 20 or more years old & $40.67 \%$ & $18.35 \%$ \\
\hline \multicolumn{3}{|l|}{ Firm size: } \\
\hline 5 to 99 employees & $83.88 \%$ & $96.05 \%$ \\
\hline 100 to 999 employees & $14.80 \%$ & $3.67 \%$ \\
\hline $1000+$ employees & $1.33 \%$ & $0.27 \%$ \\
\hline \multicolumn{3}{|l|}{ HC quartiles: } \\
\hline lowest & $20.56 \%$ & $31.14 \%$ \\
\hline Highest & $32.02 \%$ & $21.68 \%$ \\
\hline \multicolumn{3}{|l|}{ Workers: } \\
\hline$\%$ prime age & $75.80 \%$ & $68.88 \%$ \\
\hline$\%$ female & $47.44 \%$ & $47.93 \%$ \\
\hline$\%$ foreign born & $13.36 \%$ & $18.38 \%$ \\
\hline$\%$ white, non-Hispanic & $76.33 \%$ & $68.90 \%$ \\
\hline \multicolumn{3}{|l|}{$\begin{array}{l}\text { Relative labor productivity: } \\
\text { deviation of log (productivity) }\end{array}$} \\
\hline from 2-digit SIC mean & 0.2963 & -0.0704 \\
\hline Churning rate (1st quarter, 1997) & 0.2066 & 0.3269 \\
\hline Number of establishments & 2.28 & 1.34 \\
\hline \multicolumn{3}{|l|}{ Industry: } \\
\hline Construction & $5.19 \%$ & $4.22 \%$ \\
\hline Manufacturing & $14.57 \%$ & $9.77 \%$ \\
\hline Transportation & $4.28 \%$ & $5.07 \%$ \\
\hline Wholesale trade & $13.76 \%$ & $7.81 \%$ \\
\hline Retail trade & $10.66 \%$ & $29.08 \%$ \\
\hline Finance & $8.69 \%$ & $6.34 \%$ \\
\hline Services & $42.42 \%$ & $37.28 \%$ \\
\hline
\end{tabular}

Notes: All figures are for the $1997 \mathrm{BR} / 5500$ sample matched to the UI data as well, which is a subset of the overall BR/5500 sample. Corresponds to the sample used in table 13.3, third column.

\section{References}

Abowd, J. M., P. A. Lengermann, K. L. McKinney. 2002. The Measurement of Human Capital in the U.S. Economy. Longitudinal Employer-Household Dynamics (LEHD) Technical Paper no. TP-2002-09, U.S. Census Bureau.

Bulow, J. I. and L. H. Summers. 1986. A theory of dual labor markets with application to industrial policy, discrimination, and keynesian unemployment." Journal of Labor Economics 4 (3, part 1): 376-414. 
Burgess, S., J. Lane, and D. Stevens. 2000. Job flows, worker flows, and churning. Journal of Labor Economics 18 (3): 473-502.

Decressin, A., J. Lane, K. McCue, and M. Stinson. 2005. Employer-provided benefit plans, workforce composition, and firm outcomes. Technical Paper TP-2005-01, Longitudinal Employer-Household Dynamics (LEHD), U.S. Census Bureau.

Decressin, A., K. McCue, and M. Stinson. 2003. Describing the form 5500business register match. Technical Paper TP-2003-05, Longitudinal EmployerHousehold Dynamics (LEHD), U.S. Census Bureau.

Dickens, W. T. and K. Lang. 1985. A test of dual labor market theory. American Economic Review 75 (4): 792-805.

Dorsey, S., C. Cornwell, and D. Macpherson. 1998. Pensions and Productivity. Kalamazoo, MI: W. E. Upjohn Institute for Employment Research.

Ehrenberg, R. and R. Smith. 1996. Modern Labor Economics: Theory and Public Policy, 6th edition. Reading, MA: Addison-Wesley.

Even, W. E. and D. A. Macpherson. 1996. Employer size and labor turnover: The role of pensions. Industrial and Labor Relations Review 49 (4): 707-28.

- 2001. Benefits and productivity. Pension Research Council Working Paper 2001-16.

Gustman, A. L., O. S. Mitchell, and T. L. Steinmeier. 1994. The role of pensions in the labor market: A survey of the literature. Industrial and Labor Relations Review 47 (3): 417-38.

Gustman, A. L., and T. L. Steinmeier. 1993. Pension portability and labor mobility: Evidence from the SIPP. Journal of Public Economics 50 (2): 299-323.

. 1995. Pension incentives and job mobility. Kalamazoo, MI: W. E. Upjohn Institute for Employment Research.

Ippolito, R. A. 1997. Pension plans and employee performance: Evidence, analysis, and policy. Chicago: The University of Chicago Press.

. 2002. Stayers as 'workers' and 'savers': Toward reconciling the pensionquit literature. Journal of Human Resources 37 (2): 275-308.

Montgomery, E., and K. Shaw. 1992. Pensions and wage premia. NBER Working Paper no. 3985. Cambridge, MA: National Bureau of Economic Research, January.

Staff of the LEHD Program. 2002. The Longitudinal Employer-Household Dynamics Program: Employment dynamics estimates project versions 2.2 and 2.3. Technical Paper TP-2002-05-rev1, LEHD, U.S. Census Bureau.

\section{Comment Dan A. Black}

Decressin, Hill, McCue, and Stinson (DHMS henceforth) should be congratulated for a very good chapter. Moreover, the profession owes them a debt of gratitude for their efforts to create this intriguing data set. Economists are heavy users of data sets, but we seem to undervalue the effort and creativity associated with the creation of data. The authors of this chapter have done an immense amount of work creating an important data set that

Dan A. Black is a professor at the Irving B. Harris Graduate School of Public Policy Studies, University of Chicago, and a senior fellow at the National Opinion Research Center (NORC) at the University of Chicago. 